Review

\title{
Serum biomarkers in Acute Respiratory Distress Syndrome an ailing prognosticator
} Argyris Tzouvelekis ${ }^{1}$, Ioannis Pneumatikos ${ }^{2}$ and Demosthenes Bouros*2

Address: ${ }^{1}$ Interstitial Lung Disease Unit, Royal Brompton Hospital, Imperial College, Faculty of Medicine London, UK and ${ }^{2}$ Department of Pneumonology, Medical School, Democritus University of Thrace, Greece

Email: Argyris Tzouvelekis - atzouvelekis@yahoo.gr; Ioannis Pneumatikos - pneumat@med.duth.gr; Demosthenes Bouros* - bouros@med.duth.gr

* Corresponding author

Published: 22 June 2005

Respiratory Research 2005, 6:62 doi:10.1 186/1465-9921-6-62
Received: 0I April 2005

Accepted: 22 June 2005

This article is available from: http://respiratory-research.com/content/6/1/62

(C) 2005 Tzouvelekis et al; licensee BioMed Central Ltd.

This is an Open Access article distributed under the terms of the Creative Commons Attribution License (http://creativecommons.org/licenses/by/2.0), which permits unrestricted use, distribution, and reproduction in any medium, provided the original work is properly cited.

\begin{abstract}
The use of biomarkers in medicine lies in their ability to detect disease and support diagnostic and therapeutic decisions. New research and novel understanding of the molecular basis of the disease reveals an abundance of exciting new biomarkers who present a promise for use in the everyday clinical practice. The past fifteen years have seen the emergence of numerous clinical applications of several new molecules as biologic markers in the research field relevant to acute respiratory distress syndrome (translational research). The scope of this review is to summarize the current state of knowledge about serum biomarkers in acute lung injury and acute respiratory distress syndrome and their potential value as prognostic tools and present some of the future perspectives and challenges.
\end{abstract}

\section{Introduction}

The use of biomarkers in medicine lies in their ability to detect disease and support diagnostic and therapeutic decisions. New research and novel understanding of the molecular basis of the disease reveals an abundance of exciting new biomarkers who present a promise for use in the everyday clinical practice.

The initial evaluation of a serum biomarker concerns its expression in patients with the disease and in normal individuals in order to define sensitivity and specificity. The sensitivity of a test is defined as the proportion of patients with disease having a positive test whereas the specificity is the proportion of patients without the disease who have a negative or normal test. Consequently the serum level of an ideal marker should: 1) increase pathologically in the presence of the disease (high sensitivity), 2) not increase in the absence of the disease (high specificity), 3) relate to the disease burden and extent, 4) change in accordance with the clinical evolution, reflecting the current status of disease, or better 5) anticipate clinical changes, i.e. indicating the presence of relapse before it becomes obvious at a clinical level and finally 6 ) possess constant serum levels (no major fluctuation) [1].

Additionally, a clinically suitable biomarker should fulfil the following requirements [2]:

1. add independent information about the risk or prognosis 
Table I: List of studied serum biomarkers in ARDS

\begin{tabular}{|c|c|}
\hline \multirow{5}{*}{$\begin{array}{l}\text { Lung epithelium- } \\
\text { specific proteins }\end{array}$} & Surfactant-associated proteins \\
\hline & - SP-A \\
\hline & - SP-B \\
\hline & - SP-D \\
\hline & $\begin{array}{c}\text { Mucin-associated antigens } \\
\cdot \mathrm{KL}-6 / \mathrm{MUCI}\end{array}$ \\
\hline \multirow[t]{7}{*}{ Cytokines } & - IL-I \\
\hline & $\cdot$ IL-2 \\
\hline & - IL-6 \\
\hline & - IL-8 \\
\hline & $\cdot$ IL-10 \\
\hline & $\cdot \mid \mathrm{LL}-15$ \\
\hline & - TNFa \\
\hline \multirow{7}{*}{$\begin{array}{l}\text { Other serological } \\
\text { parameters }\end{array}$} & Markers of endothelium activation \\
\hline & $\begin{array}{l}\text { • Adhesion molecules } \\
\text { (E, L-selectin, I-CAM-I, V-CAM-I) }\end{array}$ \\
\hline & $\cdot V W F$ \\
\hline & Markers of neutrophil activation \\
\hline & - MMP-9 \\
\hline & - LTB4 \\
\hline & Ferritin \\
\hline
\end{tabular}

Abbreviations: ARDS: Acute Respiratory Distress Syndrome, $\mathrm{CCI}$ : Clara-cell protein 16, IL: Interleukin, KL-6: Krebs von den Lungen-6, LTB4: Leukotriene B4 MMP-9: Metalloproteinase-9 MUC: Mucin, ICAM-I: Intercellular Adhesion Molecule-I, sIL-2R: soluble interleukin2 receptor, V-CAM-I: Vascular Adhesion Molecule-I, VWF: von Willebrand factor antigen

2. account for a large proportion of the risk associated with a given disease or condition

3. be reproducible (as determined by the low coefficient of variation)

4. be sensitive, specific and should present with a high predictive value

\section{5. be of easy and cheap determination}

Very few markers present a threshold at which the risk suddenly rises. The interplay between sensitivity and specificity and the nature of the disease under prediction assigns suitable cut-off points. Sensitivity and specificity calculated at various cut-off points give rise to a receiveroperating-characteristic (ROC) curve [2]. A clinically useful biomarker will be one with the largest area under the ROC curve. A number of novel blood biomarkers of lung disease including cytokines, enzymes, adhesion molecules, collagen relevant products and products of type II epithelial cells, have been studied for their clinical applicability.

The scope of this review is based on the fact that although there are numerous published papers investigating the utility of biomarkers in the clinical research field the number of review articles summarizing the current state of knowledge about the clinical applications of these molecules as diagnostic and prognostic tools in the research field relevant to acute respiratory distress syndrome (ARDS) and acute lung injury (ALI) still remains inadequately small.

\section{Serum biomarkers in Acute Respiratory Distress syndrome}

ARDS is a clinical and pathophysiologic entity characterized by severe acute injury, directly or indirectly via the blood, to the endothelial and epithelial surfaces of the lung leading to respiratory failure. The main characteristics of the syndrome are diffuse inflammation and increased microvascular permeability that cause diffused interstitial and alveolar oedema and persistent refractory hypoxemia [3]. Although a variety of insults may lead to ARDS, a common pathway may probably result in the lung damage $[4,5]$. A complex series of inflammatory events have been recognized during the development of ARDS but the exact sequence of the events remains elusive. Immunological studies investigating bronchoalveolar lavage fluid (BALF) have shed further light into the pathogenetic mechanisms of ARDS [6] and formed the basis of concepts of its immunopathogenesis. A large variety of inflammatory mediators (Table 1 ) have been found to be elevated in the early phase of ARDS, including lungspecific proteins, endotoxin binding proteins, tumor necrosis-alpha (TNFa), interleukins - (ILs) - 1, 2, 6, 8, 15, chemokines, ferritin, markers of endothelium activation (adhesive molecules and von-Willebrand factor antigenVWF) as well as markers of neutrophil activation such as matrix metalloproteinases (MMPs) and their inhibitors and leukotrienes [5-7]. The majority of these molecules have features to recommend them as biologic markers in ARDS. Biomarkers have attracted a lot of attention in both ALI and ARDS since they can shed further light into the pathogenesis and pathophysiology of lung injury. Additionally, from a practical point of view, a clinical useful biomarker for ARDS must add information regarding the development of syndrome in at-risk patients that is not apparent from routine examination and investigation. The latter, could help the intensivist to monitor the disease and evaluate or modulate treatments before they have failed. Driven by this perspective idea, many studies have estimated their usefulness as early predictors of ARDS and accurate markers of lung injury before clinical changes can be detected. 


\section{Cytokines (Tables 2 and 3)}

Table 2: Studies measuring cytokines in patients with or at risk for ARDS

\begin{tabular}{|c|c|c|c|c|c|}
\hline Investigator & $\begin{array}{l}\text { Patients } \\
\text { Controls }\end{array}$ & Biomarker / Summary & $\begin{array}{l}\text { ROC curve analysis } \\
\text { Cut-off values }\end{array}$ & $\begin{array}{l}\text { Specificity - } \\
\text { Sensitivity PPV - } \\
\text { NPV }\end{array}$ & Limitations \\
\hline Pinsky et al. 13 & 52 at risk & $\begin{array}{l}\text { Relation of IL- } 6 \text { and TNF } \\
\text { plasma levels to multiple- } \\
\text { system organ failure and } \\
\text { mortality }\end{array}$ & No & Not estimated & $\begin{array}{l}\text { Small number of patients } \\
\text { No ROC curve analysis / } \\
\text { cut-off levels } \\
\text { No serial measurement }\end{array}$ \\
\hline Takala et al. ${ }^{14}$ & $\begin{array}{l}20 \text { at risk } \\
56 \text { controls }\end{array}$ & $\begin{array}{l}\text { IL- } 6 \text { and IL- } 8 \text { plasma levels } \\
\text { predict organ failure in } \\
\text { community-acquired septic } \\
\text { shock }\end{array}$ & No & Not estimated & $\begin{array}{l}\text { Small number of patients } \\
\text { No ROC curve analysis / } \\
\text { cut-off levels } \\
\text { Poor discriminative value of } \\
\text { serum biomarkers per se }\end{array}$ \\
\hline Calandra et al. ${ }^{15}$ & 70 at risk & $\begin{array}{l}\text { IL-6 plasma levels do not } \\
\text { predict the outcome in at risk } \\
\text { patients for ARDS }\end{array}$ & No & Not reported & $\begin{array}{l}\text { Small number of patients } \\
\text { No ROC curve analysis }\end{array}$ \\
\hline Kiehl et al. ${ }^{16}$ & 19 at risk & $\begin{array}{l}\text { TNFa, IL-6, IL-8 plasma levels } \\
\text { fail to associate with severity } \\
\text { and course of ARDS in } \\
\text { leukocytopenic patients }\end{array}$ & No & Not estimated & $\begin{array}{l}\text { Small number of patients } \\
\text { No ROC curve analysis / } \\
\text { cut-off levels } \\
\text { Leukocytopenic patients }\end{array}$ \\
\hline Meduri et al. ${ }^{18}$ & 27 ARDS & $\begin{array}{l}\text { TNFa, IL-I } \beta \text {, IL-2, IL-4, IL-6, } \\
\text { IL-8 } \\
\text { Superiority of IL-I } \beta \text { and IL-6 } \\
\text { plasma levels in monitoring } \\
\text { disease activity over } \\
\text { commonly applied } \\
\text { clinicophysiologic } \\
\text { parameters. }\end{array}$ & $\begin{array}{l}\text { Yes } \\
\text { TNFa: } 400 \mathrm{pg} / \mathrm{ml} \\
\text { IL-I } \beta: 400 \mathrm{pg} / \mathrm{ml} \\
\text { IL-2: } 200 \mathrm{pg} / \mathrm{ml} \\
\text { IL-4: } 200 \mathrm{pg} / \mathrm{ml} \\
\text { IL-6: } 400 \mathrm{pg} / \mathrm{ml} \\
\text { IL-8: } 400 \mathrm{pg} / \mathrm{ml}\end{array}$ & $\begin{array}{l}\text { TNFa: } 89-50-85-57 \% \\
\text { IL-I } \beta: 78-83-83-78 \% \\
\text { IL-2: } 89-83-90-80 \% \\
\text { IL-4: } 89-50-85-57 \% \\
\text { IL-6: } 77-75-8 I-70 \% \\
\text { IL-8: } 66-50-66-50 \%\end{array}$ & $\begin{array}{l}\text { Small number of patients } \\
\text { Perspective study } \\
\text { Overlap of cytokine levels } \\
\text { between survivors and non- } \\
\text { survivors } \\
\text { Heterogeneity of studied } \\
\text { population } \\
\text { Definition criteria of ARDS }\end{array}$ \\
\hline Agouridakis et al. ${ }^{19}$ & $\begin{array}{l}8 \text { ARDSa } \\
26 \text { at risk }\end{array}$ & $\begin{array}{l}\text { Association between } \\
\text { increased levels of IL-2 and } \\
\text { IL- } 15 \text { and outcome in patients } \\
\text { with early ARDS }\end{array}$ & $\begin{array}{l}\text { Yes } \\
\text { IL-2: } 173 \mathrm{pg} / \mathrm{ml} \\
\text { IL-I5: } 250 \mathrm{pg} / \mathrm{ml}\end{array}$ & $\begin{array}{l}\text { IL-2: } 100-100-100- \\
100 \% \text { IL- I5: } 100-100- \\
100-100 \%\end{array}$ & $\begin{array}{l}\text { Small number of patients } \\
\text { Limited number of studied } \\
\text { molecules }\end{array}$ \\
\hline
\end{tabular}

Abbreviations: ARDS: Acute Respiratory Distress Syndrome, BALF: Bronchoalveolar lavage Fluid, IL: Interleukin, NPV: Negative Predictive Value, PPV: Positive Predictive Value, ROC: Receiver Operating Characteristic, sIL-2R: soluble interleukin-2 receptor, TNFa: Tumor Necrosis Factoralpha

a: Use the American European Consensus Conference definitions

Cytokines are widely recognized as mediators of an inflammatory response. Their discovery has stimulated multidisciplinary investigation to elucidate the role of these mediators in the injury and repair processes of human disease. In the lung, they are produced either by local resident cells such as alveolar macrophages, pneumocytes, endothelial cells and fibroblasts or by cells such as neutrophils, lymphocytes and platelets arriving to the lung in response to local or systemic injury $[8,9]$. Cytokines are involved both in the early (TNFa, IL-1, 2, 6, $8,15)$ and late phase (IL-4) of inflammation and have been shown unequivocally to be of crucial importance in the pathophysiology of septic shock, a condition frequently culminating to ARDS $[10,11]$.

Studies have demonstrated that in ARDS patients detectable cytokine serum levels are closely related to the disease severity and mortality $[11,12]$, suggesting a potential role in reflecting the severity of the lung injury. Moreover, humoral (IL-6, IL-8) and cellular markers (CD 11b) of sys- temic inflammation have been delineated to identify patients with septic shock at risk for organ failure, culminating to a fatal outcome $[13,14]$. However, their monitoring and prognostic value in septic-shock patients still remains controversial. Calandra et al. [15] stated that serum cytokines could not be used as a routine laboratory test to predict the outcome in septic-shock patients. In addition, Kiehl et al. [16] failed to prove usefulness of plasma cytokines measurement for the evaluation of severity and course of ARDS in a small cohort of leukocytopenic septic-shock patients. In the same study, estimation of BALF levels appeared to differentiate between responders and non-responders to treatment before clinical differences become apparent. Nonetheless, it should be noted that the small sample size, the contradictive results, the lack of standardization techniques and uniform definitions for ARDS and at risk patients, together with the heterogeneity of the syndrome and the patients studied generate major concerns regarding the reproducibility and the reliability of the data presented. Conse- 
Table 3: Studies measuring cytokines in patients with or at risk for ARDS

\begin{tabular}{|c|c|c|c|c|c|}
\hline Investigator & $\begin{array}{l}\text { Patients } \\
\text { Controls }\end{array}$ & Biomarker / Summary & $\begin{array}{l}\text { ROC curve analysis } \\
\text { Cut-off values }\end{array}$ & $\begin{array}{l}\text { Specificity - } \\
\text { Sensitivity PPV - } \\
\text { NPV }\end{array}$ & Limitations \\
\hline Lesur et al. 20 & $\begin{array}{l}19 \text { ARDS }^{\mathrm{a}} \\
14 \text { at risk } \\
20 \text { controls }\end{array}$ & $\begin{array}{l}\text { Association of early low serum } \\
\text { IL-2 levels with the patients' } \\
\text { survival }\end{array}$ & No & Not estimated & $\begin{array}{l}\text { Small number of patients } \\
\text { No ROC curve analysis / cut- } \\
\text { off levels } \\
\text { No serial measurement } \\
\text { Discrepancies in serum and } \\
\text { BALF IL-2 levels } \\
\text { Limited number of studied } \\
\text { molecules }\end{array}$ \\
\hline Parsons et al. 23 & 77 at risk & $\begin{array}{l}\text { Association of serum IL-I ra, } \\
\text { IL- I } 0 \text { levels with the disease } \\
\text { outcome }\end{array}$ & No & Not estimated & $\begin{array}{l}\text { No ROC curve analysis / cut- } \\
\text { off levels } \\
\text { Poor predictive value for } \\
\text { ARDS development } \\
\text { Limited number of studied } \\
\text { molecules }\end{array}$ \\
\hline Takala et al. 24 & $\begin{array}{l}52 \text { at risk } \\
9 \text { ARDS }^{\text {a }} \\
45 \text { controls }\end{array}$ & $\begin{array}{l}\text { IL-8, IL-6, sIL-2R, E-selectin, } \\
\text { procalcitonin } \\
\text { Persistent elevation of } \\
\text { inflammatory markers in } \\
\text { patients with ALI precedes its } \\
\text { clinical diagnosis }\end{array}$ & No & Not estimated & $\begin{array}{l}\text { Small number of non- } \\
\text { survivors } \\
\text { No ROC curve analysis / cut- } \\
\text { off levels } \\
\text { Poor predictive value for } \\
\text { ARDS development }\end{array}$ \\
\hline Bouros et al. 25 & $\begin{array}{l}32 \text { ARDS }^{a} \\
27 \text { at risk }\end{array}$ & $\begin{array}{l}\text { IL-4, IL-6, IL-6r, IL-8, IL- I0 } \\
\text { High prognostic value of all the } \\
\text { inflammatory markers in } \\
\text { assessing the outcome in } \\
\text { patients with or at risk for } \\
\text { ARDS }\end{array}$ & $\begin{array}{l}\text { Yes } \\
\text { IL-4: } 84 \mathrm{pg} / \mathrm{ml} \\
\text { IL-6: } 160 \mathrm{pg} / \mathrm{ml} \\
\text { IL-6r: } 18 \mathrm{pg} / \mathrm{ml} \\
\text { IL-8: } 2340 \mathrm{pg} / \mathrm{ml} \\
\text { IL-I0: } 98 \mathrm{pg} / \mathrm{ml}\end{array}$ & $\begin{array}{l}\text { IL-4: } 78-100-81-100 \% \\
\text { IL-6: } 59-96-69-94 \% \\
\text { IL-6r: } 78-76-76-78 \% \\
\text { IL-8: } 93-96-92-96 \% \\
\text { IL-I0: } 96-92-96-93 \%\end{array}$ & $\begin{array}{l}\text { Small sample size } \\
\text { No serial measurement } \\
\text { Grouping and definition } \\
\text { criteria }\end{array}$ \\
\hline Schutte et al. 26 & $\begin{array}{l}30 \text { ARDSa } \\
44 \text { at risk } \\
\text { I7 controls }\end{array}$ & $\begin{array}{l}\text { IL-6, IL-8, TNFa } \\
\text { Serum levels of IL-6 and IL-8 in } \\
\text { ARDS and/or severe } \\
\text { pneumonia, differentiate these } \\
\text { entities from cardiogenic } \\
\text { pulmonary oedema }\end{array}$ & No & Not estimated & $\begin{array}{l}\text { Small number of patients } \\
\text { Weak correlations with } \\
\text { clinical variables } \\
\text { No definitive predictive value } \\
\text { for outcome } \\
\text { Overlap of cytokine levels } \\
\text { between survivors and non- } \\
\text { survivors } \\
\text { No ROC curve analysis / cut- } \\
\text { off levels }\end{array}$ \\
\hline Bauer et al. 27 & $\begin{array}{l}46 \text { ARDSa } \\
20 \text { at risk } \\
10 \text { controls }\end{array}$ & $\begin{array}{l}\text { IL-6, IL-Ib, TNFa serum levels } \\
\text { associate better with the } \\
\text { degree of lung injury rather } \\
\text { than clarify its specific aetiology }\end{array}$ & No & Not estimated & $\begin{array}{l}\text { Corticosteroid treatment } \\
\text { Inconclusive prognostic value } \\
\text { No serial measurement } \\
\text { Limited number of studied } \\
\text { molecules }\end{array}$ \\
\hline
\end{tabular}

Abbreviations: ARDS: Acute Respiratory Distress Syndrome, BALF: Bronchoalveolar lavage Fluid, IL-I ra: Interleukin-receptor antagonist, NPV: Negative Predictive Value, PPV: Positive Predictive Value, ROC: Receiver Operating Characteristic, sIL-2R: soluble interleukin-2 receptor, TNFa: Tumor Necrosis Factor-alpha

a: Use the American European Consensus Conference definitions

quently, there is a need for further large scale investigations in the context of appropriate clinical trials for any meaningful conclusions to be reached.

Evidence from preceding studies [11-13,16] give credence to the view that the inability of the lung to repair after ALI is the result of a persistent inflammatory stimulus that ultimately leads to an unfavorable outcome [17]. Fueled by this prospect, Meduri and coworkers [18] indicated a consistent, efficient and independent predictive value for
IL-1 $\beta$ and IL-6 serological concentrations over time in a small cohort of patients with severe ARDS. They generated ROC curve analysis and demonstrated a clear superiority of inflammatory cytokines in monitoring disease activity over commonly applied clinicophysiologic parameters. However, this study exhibited substantial weaknesses including the retrospective analysis, the small sample size and the overlapping results between survivors and nonsurvivors. These observations coupled with the heterogeneity of the disease and the evidence that elevated serum 
cytokines may reflect the increased production or decreased clearance and not the disease activity pose major limitations to the aforementioned findings.

In another study, Agouridakis et al. [19] evaluated both the prognostic and predictive significance of IL-2 and IL15 for the development and outcome of patients at risk who developed ARDS or patients at risk who never developed ARDS, respectively. They applied ROC curve analysis and showed an excellent predictive value of cytokine plasma levels in terms of specificity and sensitivity compared to those observed in BALF. The most remarkable ascertainment of this study was the emergence of the discriminative usefulness of elevated IL-2 and IL-15 serological concentrations in patients with ARDS or at risk for ARDS. Nevertheless, the small number of patients enrolled combined with the lack of serial measurements throughout the clinical course of the disease and the causal diversity of the syndrome render major uncertainty to these findings.

On the contrary with other analyses $[16,18]$, Lesur et al [20] found lower blood IL-2 levels in patients with ARDS compared to those that never developed the syndrome. In addition, evidence of this study regarding the strong association of early low serum IL-2 levels with the patients' survival corroborated earlier findings [16]. Potential criticism of this study include the small number of patients recruited, the absence of multiple time-point evaluation of the cytokine plasma concentrations and more importantly opposite and disproportional fluctuations of IL-2 content in serum and BALF in patients with or without ARDS.

The role of several inflammatory cytokines in monitoring the disease activity and predicting the survival in patients with ARDS has aroused increasing attention the past decade. One of the most intriguing aspects of the application of these biomarkers in the daily clinical practice is the early detection of patients admitted to the intensive care unit (ICU) that will develop ARDS. This approach will allow anti-inflammatory and other supportive treatments to be evaluated or eventually modified before they have failed. Predictive levels of inflammatory cytokines (IL-1, IL-2, IL-6, IL-8) for ARDS development in at risk patients have been extensively reported with controversial results $[16,17,21,22]$. The importance of considering inflammatory constituents of serum in patients at risk for ARDS was initially raised by Parsons et al [23]. Authors conducted a large prospective analysis and demonstrated that although immunological parameters (IL-1ra and IL-10) were elevated in patients at risk for ARDS and exhibited a remarkable association with the disease outcome, none of these could predict the development of the syndrome.
These observations were extended by the results of Takala et al. [24] who showed that serum levels of inflammatory mediators albeit their persistent elevation in patients with unresolving ALI, preceding its clinical diagnosis, were of poor discriminative value in patients with ALI that did or did not develop ARDS. Nevertheless, these findings provided us with useful knowledge about the inflammation marker profile on the days preceding diagnosis of ARDS, indicating a potential relation of sustained inflammatory response with a poor outcome.

With this aim in mind, Bouros et al. [25] measured prospectively a slew of cytokines in the serum and BALF in ICU patients to identify predictive factors for the course and outcome of ARDS. The most remarkable result of this analysis was that almost all serum molecules studied showed a high prognostic value in assessing the outcome in patients with or at risk for ARDS. However, laboratory parameters failed to prove a positive correlation with the prediction of ARDS development evidence consistent with earlier studies $[23,24]$. Moreover, major caveats that should be taken under consideration include the limited number of patients, the lack of sufficient follow-up serum data and the marked causal heterogeneity of the syndrome that could be a reason for the contradictive results reported in previous studies [20,23-25]. Further prospective studies with sufficient statistical power are required to validate these results and ameliorate the predictive role of circulating inflammatory mediators in patients at risk for ARDS.

Although the role of cytokines in the pathogenesis of ARDS has been extensively investigated, their importance in the differential diagnosis has not been clearly defined. It is widely accepted that numerous insults may lead to ARDS following a common pathway. Furthermore, a variety of conditions including severe pneumonia imitate clinical and radiological manifestations of ARDS and thereby it is often difficult to differentiate them. However, this would be a fruitful application because the treatment of these conditions differs considerably. Many groups of investigators have attempted to produce a discriminative systematic inflammatory profile and although much good work has been done towards this direction, the results still remain controversial.

Schutte and co-workers [26] provided us with a really well done and heavily informative paper concerning the systemic cytokine profile in patients with ARDS, severe pneumonia and cardiogenic pulmonary oedema. Authors found remarkably and consistently elevated serum levels of IL- 6 and IL-8 in ARDS and/or severe pneumonia, differentiating these entities from cardiogenic pulmonary oedema. Nevertheless, they were unable to separate the various entities of ARDS and states of severe pneumonia 
Table 4: Studies measuring markers of endothelium activation in patients with or at risk for ARDS

\begin{tabular}{|c|c|c|c|c|c|}
\hline Investigator & $\begin{array}{l}\text { Patients } \\
\text { Controls }\end{array}$ & Biomarker / Summary & $\begin{array}{l}\text { ROC curve analysis } \\
\text { Cut-off values }\end{array}$ & $\begin{array}{l}\text { Specificity - } \\
\text { Sensitivity PPV-NPV }\end{array}$ & Limitations \\
\hline Donnelly et al. 39 & $\begin{array}{l}82 \text { at risk } \\
\text { I4 ARDSa } \\
62 \text { controls }\end{array}$ & $\begin{array}{l}\text { E-selectin levels were not } \\
\text { correlated with ARDS } \\
\text { development and patients' } \\
\text { mortality. L-selectin levels } \\
\text { exhibited a significant } \\
\text { prognostic value }\end{array}$ & No & Not estimated & $\begin{array}{l}\text { Heterogeneity of studied } \\
\text { population (trauma- } \\
\text { sepsis) } \\
\text { No ROC curve analysis / } \\
\text { cut-off levels No serial } \\
\text { measurement }\end{array}$ \\
\hline Boldt et al. 40 & 50 at risk & $\begin{array}{l}\text { Constantly lower E-selectin, } \\
\text { ICAM-I and VCAM-I levels } \\
\text { in survivors experiencing } \\
\text { polytrauma than in } \\
\text { nonsurvivors }\end{array}$ & No & Not estimated & $\begin{array}{l}\text { Small sample size } \\
\text { Causal diversity of patient } \\
\text { group } \\
\text { No definitive association } \\
\text { with patients' mortality } \\
\text { No ROC curve analysis / } \\
\text { cut-off levels }\end{array}$ \\
\hline Cowley et al. ${ }^{4 l}$ & $\begin{array}{l}40 \text { SIRS } \\
85 \text { controls }\end{array}$ & $\begin{array}{l}\text { Superiority of E-selectin } \\
\text { plasma levels in predicting } \\
\text { organ dysfunction and death } \\
\text { patients with SIRS } \\
\text { comparing to ICAM-I }\end{array}$ & No & Not estimated & $\begin{array}{l}\text { Small number of patients } \\
\text { Causal diversity of } \\
\text { patients studied } \\
\text { No ROC curve analysis / } \\
\text { cut-off levels }\end{array}$ \\
\hline Sessler et al. 43 & $\begin{array}{l}25 \text { at risk } \\
12 \text { controls }\end{array}$ & $\begin{array}{l}\text { Association of elevated } \\
\text { ICAM-I } \\
\text { Sequential plasma levels } \\
\text { with the severity of shock }\end{array}$ & $\begin{array}{l}\text { Yes } \\
\text { ICAM-I: } 715 \mathrm{ng} / \mathrm{ml} \\
\text { (predicting survival) }\end{array}$ & Not reported & $\begin{array}{l}\text { Small sample size } \\
\text { Heterogeneity of studied } \\
\text { population } \\
\text { Inconclusive association } \\
\text { with disease Severity }\end{array}$ \\
\hline Kayal et al. 44 & $\begin{array}{l}32 \text { at risk } \\
9 \text { controls }\end{array}$ & $\begin{array}{l}\text { Cut off values of E-selectin, } \\
\text { ICAM-I and VWF serum } \\
\text { levels predicted survival } \\
\text { outcome }\end{array}$ & $\begin{array}{l}\text { Yes } \\
\text { E-selectin: } 128 \mathrm{ng} / \mathrm{ml} \\
\text { ICAM-I: } 715 \mathrm{ng} / \mathrm{ml} \\
\text { VWF: } 717 \%\end{array}$ & $\begin{array}{l}\text { E-selectin: } 73-80-67-85 \% \\
\text { ICAM-I: } 80-90-75-92 \% \\
\text { VWF: } 87-8080-87 \%\end{array}$ & $\begin{array}{l}\text { Small number of patients } \\
\text { Most of the patients } \\
\text { developed secondary ALI }\end{array}$ \\
\hline Agouridakis et al. 45 & $\begin{array}{l}23 \text { ARDSa } \\
42 \text { at risk }\end{array}$ & $\begin{array}{l}\text { TNFa, IL-I, ICAM-I, } \\
\text { VCAM-I } \\
\text { ICAM-I and VCAM-I } \\
\text { showed a high NPV for } \\
\text { ARDS development } \\
\text { Correlation with the } \\
\text { disease outcome } \\
\text { None of the studied } \\
\text { markers was an } \\
\text { independent factor for } \\
\text { ARDS development }\end{array}$ & $\begin{array}{l}\text { Yes } \\
\text { TNFa: } 325 \mathrm{pg} / \mathrm{ml} \\
\text { IL-I: } 225 \mathrm{pg} / \mathrm{ml} \\
\text { ICAM-I: } 300 \mathrm{pg} / \mathrm{ml} \\
\text { VCAM-I: } 260 \mathrm{pg} / \mathrm{ml}\end{array}$ & $\begin{array}{l}\text { For ARDS development } \\
\text { TNFa: } 62-75-38-89 \% \\
\text { IL-I: } 58-88-39-94 \% \\
\text { ICAM-I: } 69-75-42-90 \% \\
\text { VCAM-I: } 73-88-50-95 \%\end{array}$ & $\begin{array}{l}\text { Small sample size } \\
\text { No serial measurement } \\
\text { None of the studied } \\
\text { markers was an } \\
\text { independent factor for } \\
\text { ARDS development }\end{array}$ \\
\hline
\end{tabular}

Abbreviations: ALI: Acute Lung Injury, ARDS: Acute Respiratory Distress Syndrome, ICAM-I: Intercellular Cell Adhesion Molecule-I, IL: Interleukin, ROC: Receiver Operating Characteristic, SIRS: Systematic Inflammatory Response Syndrome, TNFa: Tumor Necrosis Factor-alpha, VCAM-I: Vascular Cell Adhesion Molecule-I, VWF: von Willebrand factor antigen, a: Use the American European Consensus Conference definitions

based solely on alterations in the immunomodulatory pattern.

To streamline these observations, Bauer et al. [27] tested the potential of inflammatory markers (TNFa, IL-1 $\beta$, IL-6) to differentiate between these two diseases. Results in harmony with the previous study [26] demonstrated higher TNFa serological concentrations in patients with ARDS from the remaining populations. However, they revealed the ability of immunological parameters to associate better with the degree of lung injury rather than clarify its specific aetiology. No clear relationship between serological data and patients' survival was observed. In addition, this data exhibits major limitations, including the absence of uniform methodology (use of corticosteroid treatment in some of the patients), serial measurements and the lack of knowledge regarding serum alterations in other components of the inflammatory network (Tables 2 and 3 ).

\section{Other serological parameters}

Markers of endothelium activation (Tables 4 and 5)

The pathophysiologic sequence characterizing ALI involves apart from cytokine, free radical, proteases and aracidonic acid metabolites release, the endothelial and neutrophil activation which initiate a cascade of leukocyte-endothelium interactions and adhesions. This is fol- 
Table 5: Studies measuring markers of endothelium activation in patients with or at risk for ARDS

\begin{tabular}{|c|c|c|c|c|c|}
\hline Investigator & $\begin{array}{l}\text { Patients } \\
\text { Controls }\end{array}$ & Biomarker / Summary & $\begin{array}{l}\text { ROC curve analysis } \\
\text { Cut-off values }\end{array}$ & $\begin{array}{l}\text { Specificity - } \\
\text { Sensitivity PPV- } \\
\text { NPV }\end{array}$ & Limitations \\
\hline Rubin et al. 47 & 45 at risk & $\begin{array}{l}\text { Elevated plasma VWF is an } \\
\text { early predictor of ALI in } \\
\text { nonpulmonary sepsis } \\
\text { syndrome }\end{array}$ & $\begin{array}{l}\text { Yes } \\
\text { VWF: } 450 \%\end{array}$ & $77-87-80 \%$ & $\begin{array}{l}\text { Small sample size } 25 \% \text { of } \\
\text { patients had already lung } \\
\text { injury at the time sepsis was } \\
\text { diagnosed } \\
\text { Exclusion of patients who } \\
\text { developed } \\
\text { ALI from a primary } \\
\text { pulmonary source VWF } \\
\text { levels measured by an old } \\
\text { assay }\end{array}$ \\
\hline Ware et al. 48 & $\begin{array}{l}5 \text { I ALI/ ARDSa } \\
4 \text { controls }\end{array}$ & $\begin{array}{l}\text { VWF is an independent } \\
\text { predictor of hospital mortality } \\
\text { in patients with ALI }\end{array}$ & $\begin{array}{l}\text { No } \\
\text { VWF:450\% }\end{array}$ & $91-44-83-62 \%$ & $\begin{array}{l}\text { Inadequate sample volume } \\
\text { Heterogeneity of studied } \\
\text { population } \\
\text { No ROC curve analysis }\end{array}$ \\
\hline Ware et al. 49 & $\begin{array}{l}559 \\
\text { ALI/ ARDSa }\end{array}$ & $\begin{array}{l}\text { Significant correlation of } \\
\text { elevated VWF plasma levels } \\
\text { with mortality, duration of } \\
\text { unassisted ventilation and } \\
\text { organ failures. No differences } \\
\text { of WWF levels between septic } \\
\text { and non septic patients }\end{array}$ & No & Not estimated & $\begin{array}{l}\text { Not definitive association } \\
\text { with patients' mortality } \\
\text { Lack of knowledge regarding } \\
\text { the cellular source and the } \\
\text { mechanisms of elevated } \\
\text { WWF serum levels } \\
\text { No ROC curve analysis / } \\
\text { cut-off values }\end{array}$ \\
\hline Moalli et al. 50 & $\begin{array}{l}35 \text { at risk } \\
\text { I0 ARDS } \\
9 \text { controls }\end{array}$ & $\begin{array}{l}\text { VWF levels were higher in } \\
\text { ARDS compared with at risk } \\
\text { WWF levels are not helpful in } \\
\text { predicting ARDS development }\end{array}$ & No & Not reported & $\begin{array}{l}\text { Limited number of patients } \\
\text { No ROC curve analysis / } \\
\text { cut-off values }\end{array}$ \\
\hline Moss et al. ${ }^{51}$ & 96 at risk & $\begin{array}{l}\text { WWF is not predictive of } \\
\text { development of ARDS }\end{array}$ & $\begin{array}{l}\text { Yes } \\
\text { VWF:273\% } \\
\text { VWF:399\% }\end{array}$ & $\begin{array}{l}47-70 \% \\
52-64 \%\end{array}$ & $\begin{array}{l}\text { Causal diversity of patients } \\
\text { studied } \\
\text { No definitive relation with } \\
\text { disease severity }\end{array}$ \\
\hline Sabharwal et al. 52 & $\begin{array}{l}22 \text { ARDS } \\
21 \text { at risk }\end{array}$ & $\begin{array}{l}\text { No significant association of } \\
\text { VWF blood levels with } \\
\text { patients' mortality }\end{array}$ & No & Not estimated & $\begin{array}{l}\text { Small sample size } \\
\text { Retrospective study } \\
\text { No ROC curve analysis / } \\
\text { cut-off values }\end{array}$ \\
\hline Bajaj et al. ${ }^{53}$ & $\begin{array}{l}\text { I8 ARDS } \\
15 \text { at risk } \\
27 \text { controls }\end{array}$ & $\begin{array}{l}\text { Serum VWF levels were non- } \\
\text { useful markers for predicting } \\
\text { ARDS in at risk patients }\end{array}$ & $\begin{array}{l}\text { Yes } \\
\text { VWF: } 300 \%\end{array}$ & $71-62-34 \%$ & $\begin{array}{l}\text { Limited number of patients } \\
\text { No serial measurement } \\
\text { Coexisting multisystem } \\
\text { organ failure } \\
\text { Heterogeneity of studied } \\
\text { population }\end{array}$ \\
\hline Moss et al. 54 & $\begin{array}{l}55 \text { at risk } \\
\text { I } 4 \text { ARDS } \\
\text { I I controls }\end{array}$ & $\begin{array}{l}\text { ICAM-I, E-selectin, VWF } \\
\text { Degree of endothelial } \\
\text { activation varied in patients at } \\
\text { risk for ARDS from different } \\
\text { etiologic factors }\end{array}$ & No & Not estimated & $\begin{array}{l}\text { Small sample size } \\
\text { Heterogeneity of studied } \\
\text { population }\end{array}$ \\
\hline
\end{tabular}

Abbreviations: ALI: Acute Lung Injury, ARDS: Acute Respiratory Distress Syndrome, ICAM-I: Intercellular Cell Adhesion Molecule-I, NPV: Negative Predictive Value, PPV: Positive Predictive Value, ROC: Receiver Operating Characteristic, VCAM-I: Vascular Cell Adhesion Molecule-I, VWF: von Willebrand factor antigen

a: Use the American European Consensus Conference definitions

lowed by transendothelial migration of neutrophils and release of their cytotoxic products, ultimately resulting to microvascular and tissue injury [28].

Adhesion of neutrophils to the endothelium is regulated by at least three adhesion molecule families including selectins (E, L and P), integrins and the immunoglobulin superfamily (intercellular adhesion molecule- ICAM-1 and vascular cell adhesion molecule-VCAM-1) and by chemotactic signals $[29,30]$. Initial interactions of leukocytes and the endothelium are mediated by members of the selectin family inducing (loose) contact with the 
endothelium also known as rolling, followed by firm adhesion requiring members of the integrin $(\beta 2)$ and immunoglobulin family (ICAM-1) [31,32].

In recent years, soluble isoforms of some of these molecules \{soluble-(s)-E-selectin, sICAM-1, sVCAM-1\} have been detected in the circulating blood under various inflammatory conditions [33-35]. Mechanisms that could potentially explain an increase in circulating adhesion molecules include cytokine-induced (IL-1, TNFa) overexpression by the endothelial cells, increased proteolytic cleavage of endothelial-bound adhesion molecules secondary to endothelial damage or both $[33,35]$. One attractive feature of these molecules and mostly E-selectin is that since their expression is almost restricted to stimulated endothelial cells [32] their presence in serum should potentially reflect the state of endothelium in disease and subsequently the disease severity in ALI.

Other potential markers of endothelial cell injury that were delineated to shed further light into the pathophysiologic process of ALI include von-Willebrand factor antigen (VWF), a macromolecular antigen that is produced predominantly by endothelial cells and to a lesser extent by platelets and megakaryocytes [36]. Endothelial perturbation (as in at risk state) or injury (as in ARDS) results to the release of VWF from preformed stores into the circulation $[37,38]$. Therefore, it appears that circulating VWF concentrations may serve as a suitable predictive marker for development of ARDS in patients at risk.

So far, the potential usefulness of adhesion molecules and other markers of endothelial cell damage in reflecting the severity of endothelial damage and predicting the development or the final outcome of the disease is a subject of ongoing controversy. One of the first and most informative studies addressing this important issue was conducted by Donnelly et al [39]. Authors demonstrated in a large cohort of patients at risk for ARDS, that mean circulating levels of sE-selectin were not correlated with subsequent ARDS development and patients' mortality. However, low values of sL-selectin exhibited a significant prognostic value. In contrast, Boldt et al. [40] studying the behaviour over $5 \mathrm{~d}$ of adhesion molecules (sE-selectin, sICAM-1 and sVCAM-1) in subjects experiencing polytrauma found constantly higher levels in nonsurvivors. In accordance to these findings, Cowley and colleagues [41] showed a superiority of sE-selectin plasma levels in predicting organ dysfunction and death in a group of patients with systemic inflammatory response (SIRS) comparing to sICAM-1 peripheral concentrations. This indicated that measurement of adhesion molecules could serve to advantage in the management of patients with sepsis. Nonetheless, the heterogeneity of patients studied (septic shock and polytraumatic) may justify these controversial results, since E-selectin expression has been found much greater in septic than in traumatic shock in experimental models [42].

Moreover, the relationship between the consequences of sepsis (organ failure, mortality) and blood levels of potential markers of endothelial-cell activation was strengthened by Sessler and co-workers [43]. Results from this study focusing on sICAM-1 sequential plasma levels, were suggestive of a strong association between the severity of shock (as determined by the presence of hypotension and the requirement of vasoactive drugs) and the circulating concentrations of the marker. The aforementioned observations were further confirmed by the study of Kayal et al [44]. Cut off values for three markers of endothelial activation were determined prospectively by ROC curve analysis and clearly predicted survival outcome with high sensitivity and specificity in a limited number of at-risk patients with secondary ALI.

Despite that the role of soluble adhesion molecules in other inflammatory conditions strongly associated with ARDS [40-44] is well known, their value as markers of the disease progression and mortality has not been extensively studied in ARDS patients. To streamline these observations, Agouridakis et al. [45] scrutinized the role of two adhesion molecules (ICAM-1, VCAM-1) in parallel with proinflammatory cytokines in predicting the ARDS development and relating to the disease outcome. None of the studied mediators was found to be an independent factor for ARDS development, whereas both groups of molecules exhibited a considerable negative predictive value for ARDS development both in serum and BALF. Additionally, ROC curve analysis showed a clear superiority of plasma parameters in correlating with the disease outcome compared with BALF molecules. Further studies with serial BALF and serum measurements should be designed to elucidate the exact role of these markers over time in reflecting the disease behaviour and predicting the likelihood of progression.

Elevated circulating concentrations of VWF in patients with ALI/ARDS were first reported in 1982 [46]. Their potential significance in predicting ARDS development was first demonstrated by Rubin and colleagues [47] who found that increased plasma levels of this marker exhibited a high predictive value both for the development of ARDS and for identifying patients with nonpulmonary sepsis who were unlikely to survive. However, authors did not use the uniform criteria for the definition of ARDS and risk state [3], evidence that poses major limitations to the results of the study.

Furthermore, in an aforementioned study, Kayal et al. [44] in parallel with other findings reported a marked and 
independent association of circulating VWF with the disease severity as assessed by other commonly applied clinical variables. These findings were further supported by a single-center study from Ware et al [48]. They conducted the first comparative study of VWF concentrations in both plasma and edema fluids of patients with early ALI from a variety of causes and reported that serum VWF levels were an independent predictor of hospital mortality and were associated with longer duration of mechanical ventilation. Potential criticisms of this study was the implementation of high tidal volume ventilation that possibly increased systemic endothelial activation, the small sample size, the lack of sequential measurement and the fact that the studied biomarker appeared not to be endothelial-specific since it is produced in small amounts by platelets [36].

To streamline these observations and ameliorate potential hardships the same group of authors \{Ware et al. [49]\} carried out a multicenter study of 559 patients with ALI and ARDS which was recently published. In accordance with earlier studies [48], a significant correlation of elevated VWF plasma levels with adverse outcomes, including mortality, duration of unassisted ventilation and organ failures was pointed out. Intriguingly, authors demonstrated for the first time a negative association between markers of endothelial activation and presence or absence of sepsis, supporting the hypothesis that ALI might be an independent cause of systemic endothelial activation and injury. Finally, in the same study no modulation of plasma VWF concentrations by protective mechanical ventilation was observed. Despite the remarkable power of the presented findings, there are substantial weaknesses that deserve further investigations including the inconclusive analysis of the plasma VWF levels associated with patients' mortality, the lack of definite knowledge regarding the source of VWF production, and the mechanisms leading to increased peripheral concentrations since the latter also could reflect decreased clearance from the circulation.

Subsequent data derived from other studies [50-54] was rather contradictive and controversial. Even though, Moalli et al. [50] found a poor predictive value of serum VWF levels for the development of ARDS in a group of at risk patients, the biomarker concentrations were correlated with the disease severity,. Similarly, Moss et al. [51] plotted ROC curves and concluded that in patients at risk for ALI/ARDS from multiple causes, serum VWF levels failed to reliably discriminate which patients would develop ARDS. The evidence was further validated by Sabharwal et al [52]. Authors conducted the first study comparing plasma levels between survivors and nonsurvivors in a group of patients both at risk for and with established ARDS and observed no significant association of VWF blood levels with patients' mortality ;predictive value of the marker was not reported. In agreement with the previous study, a study from the same group of scientists \{Bajaj et al. [53]\} using standard criteria for the definition of ARDS and at risk state [3] demonstrated the inability of three endothelial-specific proteins including VWF to predict the progression of ARDS in at risk patients. Nonetheless, major caveats that should be addressed include the fact that many at-risk patients had already some degree of ALI, the lack of serial measurement that could potentially show a trend towards prediction of ARDS development and the causal diversity of patients examined that could possibly affect the results of the study. The latter limitation was addressed by Moss et al. [54] who established that the degree of endothelial activation as determined by the plasma levels of VWF (higher in subjects with sepsis than patients with trauma) is not uniform in all patients at risk for developing ARDS.

Accumulated evidence from the preceding studies suggest that the etiologic diversity of patients enrolled renders major uncertainty to the reliability of the results and highlights the necessity for further prospective studies using standard criteria for the definition of ARDS and analyzing well defined and uniform group of at risk patients in order to produce knowledge of high scientific rigidity. Direct comparison of the different studies is difficult and in a way meaningless because of the use of varying definitions for ARDS and at-risk patients as well as the inclusion of different patient populations, in which of them some degree of ALI was probably already present (Tables 3a and $3 b)$.

\section{Markers of neutrophil activation (Table 6)}

Generally, it is strongly believed that ARDS arises as a result of tissue injury secondary to sequestration of inflammatory cells, tissue invasion, and secretion of cytotoxic products. Neutrophils have received much attention as key part of this process. Although ARDS has been described in neutropenic patients [16,55] there is increased evidence implicating neutrophils in most cases of ARDS. They have been reported by several studies $[56,57]$ to exert an important role in the early phase of ALI characterized by architecture remodeling, surfactant and epithelial toxicity. They use a wide array of enzymes during the process of transmigration through biological membranes such as alveolar-capillary barrier [58]. These enzymes include, metalloproteinases (MMPs) such as MMP-9 also called gelatinase B which is secreted from preformed neutrophil granules in response to a variety of stimuli including proinflammatory cytokines (IL-8, TNFa). MMP-9 is secreted as a zymogen, and then activated by a variety of other proteases such as elastase, and plays a crucial role in digesting basement membranes $[58,59]$. Therefore, it has been speculated that metallopro- 
Table 6: Studies measuring markers of neutrophil activation and ferritin in patients with or at risk for ARDS

\begin{tabular}{|c|c|c|c|c|c|}
\hline Investigator & $\begin{array}{l}\text { Patients } \\
\text { Controls }\end{array}$ & Biomarker / Summary & $\begin{array}{l}\text { ROC curve analysis } \\
\text { Cut-off values }\end{array}$ & $\begin{array}{l}\text { Specificity - } \\
\text { Sensitivity PPV - } \\
\text { NPV }\end{array}$ & Limitations \\
\hline Pugin et al. 60 & $\begin{array}{l}31 \text { at risk } \\
23 \text { ARDSa }^{2}\end{array}$ & $\begin{array}{l}\text { IL-8, MMP-2, MMP-9 } \\
\text { Plasma levels of inflammatory } \\
\text { activity are not useful markers } \\
\text { in differentiating permeability } \\
\text { from hydrostatic pulmonary } \\
\text { edema }\end{array}$ & No & Not estimated & $\begin{array}{l}\text { Measurement of circulating } \\
\text { proinflammatory cytokines } \\
\text { without the appreciation of } \\
\text { their inhibitors or receptor } \\
\text { antagonists is misleading } \\
\text { mainly due to a possible } \\
\text { neutralization } \\
\text { Small number of patients } \\
\text { No ROC curve analysis / } \\
\text { cut-off values }\end{array}$ \\
\hline Amat et al. 64 & $\begin{array}{l}2 \text { I ARDSa } \\
\text { I4 at risk }\end{array}$ & $\begin{array}{l}\text { Strong association of LTB } 4 \text { and } \\
\text { IL- } 8 \text { serum levels with the } \\
\text { patients' survival. }\end{array}$ & $\begin{array}{l}\text { Yes } \\
\text { LTB4: I } 4 \mathrm{pmol} / \mathrm{ml} \\
\text { IL-8: } 150 \mathrm{pmol} / \mathrm{ml}\end{array}$ & $\begin{array}{l}\text { LTB4 + IL-8: } 88-70- \\
85-75 \% \text { (markers of } \\
\text { mortality rate) } \\
\text { LTB4 : } 85-72-20-98 \% \\
\text { (marker of ARDS } \\
\text { development) }\end{array}$ & $\begin{array}{l}\text { Small sample size } \\
\text { Lack of adjustment with } \\
\text { the disease severity } \\
\text { Inability of LTB } 4 \text { plasma } \\
\text { levels to be an independent } \\
\text { predictive marker }\end{array}$ \\
\hline Connelly et al. 66 & $\begin{array}{l}75 \text { at risk } \\
8 \text { ARDSa }^{-}\end{array}$ & $\begin{array}{l}\text { Serum ferritin is a sensitive and } \\
\text { specific predictor of ARDS } \\
\text { development }\end{array}$ & $\begin{array}{l}\text { Yes } \\
\text { Ferritin (male): } 270 \mathrm{ng} / \mathrm{ml} \\
\text { Ferritin (female): } 680 \mathrm{ng} / \mathrm{ml}\end{array}$ & $\begin{array}{l}71-83-86-67 \% \\
90-60-82-75 \%\end{array}$ & $\begin{array}{l}\text { Limited number of ARDS } \\
\text { patients } \\
\text { Heterogeneity of studied } \\
\text { population }\end{array}$ \\
\hline Sharkey et al. 67 & $\begin{array}{l}42 \text { at risk } \\
\text { I } 6 \text { ARDS }^{a}\end{array}$ & $\begin{array}{l}\text { Correlation of ferritin plasma } \\
\text { levels with the development of } \\
\text { ARDS, multiple organ failure } \\
\text { and severity of lung injury }\end{array}$ & $\begin{array}{l}\text { Yes } \\
\text { Ferritin (male): } 270 \mathrm{ng} / \mathrm{ml} \\
\text { Ferritin (female): } 680 \mathrm{ng} / \mathrm{ml}\end{array}$ & $\begin{array}{l}64-73-75-62 \% \\
92-60-95-75 \%\end{array}$ & $\begin{array}{l}\text { Inadequate sample volume } \\
\text { Not specific cut-off values } \\
\text { Elevated serum levels may } \\
\text { reflect a systemic response } \\
\text { to a risk factor }\end{array}$ \\
\hline
\end{tabular}

Abbreviations: ARDS: Acute Respiratory Distress Syndrome, IL: Interleukin, LTB4: Leukotriene B4, MMP-Metalloproteinase, NPV: Negative Predictive Value, PPV: Positive Predictive Value, ROC: Receiver Operating Characteristic, a: Use the American European Consensus Conference definitions

teinases probing aspects of the inflammatory response could be utilized as markers of neutrophil activation and subsequently to reflect disease activity and severity, shedding further light into the pathogenesis of ARDS.

Fueled by this prospect, Pugin et al. [60] compared the concentrations of proinflammatory cytokines and collagenases in serum and pulmonary oedema fluids in a small group of patients with ARDS and hydrostatic oedema from congestive heart failure. Authors concluded that elevated pulmonary oedema levels of these mediators could differentiate between these conditions, whereas plasma levels of proinflammatory and metalloproteinase activity proved to be of poor discriminative value. The latter observation mirrors the hypothesis that the inflammatory response characterizing ARDS patients is well compartmentalized, with little spillover into the circulation and that the measurement of circulating proinflammatory cytokines without the appreciation of their inhibitors or receptor antagonists is misleading mainly due to a possible neutralization.

To gain a more comprehensive understanding on the role that neutrophils exhibit during the inflammatory cascade resulting to ALI, investigators scrutinized the utility of other chemotactic agents including leukotrienes (LTs). LTs (B4, C4, D4, E4) exert a synergistic role with IL-8 in the neutrophil influx and activation leading to a massive recruitment of neutrophils and to a catastrophic inflammatory response. Their BALF levels have been found elevated in patients with ARDS and their involvement in the alterations of microvascular permeability correlated with the accumulation of pulmonary oedema has been suggested [61-63].

Moreover, Amat et al [64] utilizing ROC curve analysis demonstrated that LTB4 plasma levels could serve as a valuable predictive marker of ARDS in terms of specificity and sensitivity. In the same study, authors performed serial measurement and reported a strong association of both LTB4 and IL-8 peripheral concentrations with the patients' survival. However, the small number of patients enrolled, the lack of adjustment with the disease severity and the inability of LTB4 plasma levels to be an independent predictive marker arise major concerns whether they could monitor disease behaviour and predict ARDS development in at risk patients (Table 6). 


\section{Ferritin (Table 6)}

Ferritin is a $480-\mathrm{kDa}$ iron-storage protein that sequesters iron in the ferric $\left(\mathrm{Fe}^{3+}\right)$ state. It has been speculated that ferritin may serve as a crucial antioxidant mediator because free iron enhances the formation of highly toxic hydroxyl radicals from superoxide anion and hydrogen peroxide. On the other hand, oxidative stress is a condition commonly seen in disorders at risk for ARDS development such as sepsis. Hence, ferritin-derived iron may aggravate oxidative damage in critically ill patients, contributing to the pathologic abnormalities encountered in ARDS. Furthermore, proinflammatory cytokines such as IL-8, IL-6 and TNFa which are increased and presumably participating in the pathogenetic derangements of ARDS have been suggested to promote ferritin synthesis $[39,65]$. Thereby, it can be concluded that elevated ferritin levels could result from oxidative stress, proinflammatory cytokines and the degree of lung injury, all conditions characterizing the pathogenesis of ARDS and subsequently can be used as prognostic and monitoring tool reflecting the likelihood of ARDS development and the disease severity.

The first study attempted to prove such correlation was conducted by Connelly et al [66]. They plotted ROC curves to estimate the utility of ferritin levels as prognostic factors and produced clinically useful cut-off points which could predict the development of ARDS with high sensitivity, specificity, negative and positive predictive value, both in male and female predominantly septic subjects. However, the heterogeneity of the etiologic factors resulting to ARDS development in at risk patients renders major uncertainty to the rigidity and reliability of the results.

To ameliorate this hardship, the same group of authors \{Sharkey et al. [67]\} generalized and extended the latter results in a homogeneous group of at-risk patients with multiple trauma demonstrating a strong correlation of initial ferritin plasma levels with the development of ARDS and multiple organ failure. In addition, an association of serum ferritin levels with the severity of lung injury as well as other markers of endothelial activation was also noted supporting the premise that elevated levels could reflect the inflammatory status encountering in ALI. Nonetheless, authors failed to detect specific predictive cut-off values suggesting that circulating concentrations of this biomarker are unable to predict per se the progression to ARDS. A possible explanation could arise from the hypothesis that elevated levels of this marker must reflect a systemic response to a risk factor, which may prove to reduce its specificity (Table 6 ).

\section{Lung epithelium-specific proteins (Table 7)}

Beyond other important functions, the lung epithelium produces complex secretions, including mucus blanket, surfactant proteins, as well as several proteins important for host defense [68].

Sampling the epithelial lining fluid by bronchoalveolar lavage (BAL) represents the common means of studying the proteins secreted by the lung epithelium and investigating their alterations in lung disorders [69]. However, the past fifteen years pioneering studies [70] showed the presence of these proteins in the bloodstream as well, even though in small amounts. Because these proteins are mainly, if not exclusively secreted within the respiratory tract, their occurrence in the vascular compartment can be explained by several hypothetical mechanisms including, leakage from the lung into the bloodstream, increased production by the alveolar type II cells or diminished clearance rates from the circulation [68].

\section{Surfactant-associated Proteins}

Pulmonary surfactant is a complex and highly surface active material covering the alveolar space of the lung. Biochemically, surfactant is a molecular mixture composed mainly of structurally heterogeneous phospholipids. A major function of pulmonary surfactant is to reduce the surface tension at the air-liquid interface of the alveolus, thereby preventing alveolar collapse on expiration. It has also been demonstrated that the surfactant contains specific proteins [71]. Four surfactant-specific proteins with different structural and functional properties have so far been identified. They were named surfactant protein(SP)-A, SP-B, SP-C and SP-D according to the chronologic order of their discovery [72] and have been divided in two distinctive groups, the low-molecular-weight hydrophobic SP-B and SP-C and the high-molecular-weighthydrophilic SP-A and SP-D. The latter belong to the collectin subgroup of the C-type lectin superfamily and are produced by two types of non-ciliated epithelial cells in the peripheral airway, Clara cells and alveolar type II cells. Studies have demonstrated that SP-B and SP-C seem to play an essential role for the adsorption of phospholipids to the air-water interface resulting to a stable phospholipids film and for the dynamic surface-tensionlowering properties [73]. Additional functions of the alveolar surfactant system include prevention of alveolar edema [74] and a pronounced influence, especially of the collectins SP-A and SP-D in the innate immune system of the lung $[75,76]$ and have been used as useful markers for confirming the diagnosis and evaluation of disease activity of various ILDs since they reflect the epithelial damage and turnover [77]. Thus, it has been speculated that alterations of SPs in biological fluids could serve as valuable markers of the severity of the lung injury or clinical outcome in ARDS patients. 
Table 7: Studies measuring lung-specific proteins in patients with or at risk for ARDS

\begin{tabular}{|c|c|c|c|c|c|}
\hline Investigator & $\begin{array}{l}\text { Patients } \\
\text { Controls }\end{array}$ & Biomarker / Summary & $\begin{array}{l}\text { ROC curve } \\
\text { analysis Cut-off } \\
\text { values }\end{array}$ & $\begin{array}{l}\text { Specificity - } \\
\text { Sensitivity } \\
\text { Diagnostic } \\
\text { accuracy }\end{array}$ & Limitations \\
\hline Doyle et al. ${ }^{81}$ & $\begin{array}{l}\text { I } 5 \text { ARDSa } \\
10 \text { at risk } \\
10 \text { controls }\end{array}$ & $\begin{array}{l}\text { SP-A is an acute indicator of } \\
\text { lung function and } \\
\text { alveolocapillary membrane } \\
\text { injury }\end{array}$ & No & Not estimated & $\begin{array}{l}\text { Small number of patients } \\
\text { No ROC curve analysis / cut-off } \\
\text { values } \\
\text { No definitive relation with disease } \\
\text { severity }\end{array}$ \\
\hline Doyle et al. 82 & $\begin{array}{l}22 \text { ARDSa } \\
10 \text { at risk } \\
33 \text { controls }\end{array}$ & $\begin{array}{l}\text { Superiority of SP-B compared to } \\
\text { SP-A plasma levels as a marker } \\
\text { of lung function and } \\
\text { alveolocapillary membrane } \\
\text { injury }\end{array}$ & No & Not estimated & $\begin{array}{l}\text { Only } 3 \text { case-control studies } \\
\text { Inadequate sample size } \\
\text { Lack of adjustment with disease } \\
\text { behaviour } \\
\text { No ROC curve analysis / cut-off } \\
\text { values }\end{array}$ \\
\hline Greene et al. ${ }^{83}$ & $\begin{array}{l}41 \text { ARDSa } \\
22 \text { at risk } \\
35 \text { controls }\end{array}$ & $\begin{array}{l}\text { SP-A, SP-B, SP-D } \\
\text { Serum changes found to be } \\
\text { neither sensitive nor specific in } \\
\text { predicting the onset of ARDS } \\
\text { and discriminating survivors } \\
\text { from non-survivors. }\end{array}$ & $\begin{array}{l}\text { Yes } \\
\text { Not reported }\end{array}$ & $\begin{array}{l}\text { Poor predictive } \\
\text { value } \\
\text { Low specificity/ } \\
\text { sensitivity }\end{array}$ & $\begin{array}{l}\text { Limited number of patients } \\
\text { Serial measurements for a short } \\
\text { period of time/ Lack of serial } \\
\text { measurement for the most severe } \\
\text { forms } \\
\text { Heterogeneity of studied population } \\
\text { Poor predictive value for serum } \\
\text { levels }\end{array}$ \\
\hline Cheng et al. ${ }^{84}$ & $\begin{array}{l}36 \text { ARDSa }^{a} \\
2 \mathrm{ALI}\end{array}$ & $\begin{array}{l}\text { SP-A levels were associated } \\
\text { with severity of clinical lung } \\
\text { injury and with disease outcome }\end{array}$ & No & Not estimated & $\begin{array}{l}\text { Small sample size } \\
\text { Causal diversity of studied } \\
\text { population } \\
\text { No serial measurement }\end{array}$ \\
\hline Greene et al. 85 & $\begin{array}{l}51 \text { at risk } \\
26 \text { ARDS }^{a} \\
16 \text { controls }\end{array}$ & $\begin{array}{l}\text { SP-A levels are predictive for at } \\
\text { risk patients who developed } \\
\text { ARDS from sepsis and } \\
\text { aspiration but not trauma }\end{array}$ & No & Not estimated & $\begin{array}{l}\text { Small sample size } \\
\text { No ROC curve analysis / cut-off } \\
\text { levels }\end{array}$ \\
\hline Bersten et al. 86 & $\begin{array}{l}54 \text { at risk } \\
9 \text { controls }\end{array}$ & $\begin{array}{l}\text { SP-B but not SP-A cut-off } \\
\text { plasma levels predict ARDS } \\
\text { development, particularly in at- } \\
\text { risk patients suffering a direct } \\
\text { lung injury }\end{array}$ & $\begin{array}{l}\text { Yes } \\
\text { SP-B: } 4.994 \mathrm{ng} / \mathrm{ml}\end{array}$ & $78-85-85-78 \%$ & $\begin{array}{l}\text { Small number of patients } \\
\text { Limited follow-up serum data } \\
\text { Most of patients had already lung } \\
\text { injury } \\
\text { Exclusion of milder at risk patients }\end{array}$ \\
\hline Eisner et al. ${ }^{87}$ & $\begin{array}{l}565 \\
\text { ALI/ ARDSa }\end{array}$ & $\begin{array}{l}\text { SP-A, SP-D } \\
\text { Attenuation of SP-D plasma } \\
\text { levels by lower volume } \\
\text { ventilation strategies }\end{array}$ & No & Not estimated & $\begin{array}{l}\text { Only } 2 \text { serial measurements } \\
\text { Heterogeneity of studied population } \\
\text { Potential selection bias } \\
\text { No ROC curve analysis / cut-off } \\
\text { levels }\end{array}$ \\
\hline Ishizaka et al. 95 & $\begin{array}{l}35 \text { at risk } \\
27 \text { ARDS }^{\text {a }} \\
21 \text { controls }\end{array}$ & $\begin{array}{l}\text { Association of optimal cut-off } \\
\text { values of KL-6 serum levels with } \\
\text { patients' mortality }\end{array}$ & $\begin{array}{l}\text { Yes } \\
\text { KL-6: } 253 \mathrm{U} / \mathrm{ml}\end{array}$ & $100-87 \%$ & $\begin{array}{l}\text { Inadequate sample volume } \\
\text { Heterogeneity of studied population }\end{array}$ \\
\hline Sato et al. ${ }^{96}$ & $\begin{array}{l}28 \text { ARDSa } \\
10 \text { controls }\end{array}$ & $\begin{array}{l}\text { Association of KL-6 serum } \\
\text { levels with variables of lung } \\
\text { injury severity and with } \\
\text { mortality rates } \\
\text { No correlation with ventilation } \\
\text { strategies }\end{array}$ & No & Not estimated & $\begin{array}{l}\text { Small sample size } \\
\text { Heterogeneity of studied group } \\
\text { No serial measurement } \\
\text { No ROC curve analysis / cut-off } \\
\text { levels } \\
\text { Diversity of ventilatory treatment }\end{array}$ \\
\hline
\end{tabular}

Abbreviations: ALI: Acute Lung Injury, ARDS: Acute Respiratory Distress Syndrome, BAL: Bronchoalveolar Lavage, KL-6: Krebs von den Lungen-6, ROC: Receiver Operating Characteristic, SP: Surfactant Protein, a: Use the American European Consensus Conference definitions

Most of our knowledge regarding changes in SP concentrations that occur in patients with or at risk for ARDS and their value in reflecting the disease severity or the likelihood of ARDS development comes from BAL studies. Several reports in the literature have demonstrated the occurrence of low SP-A levels in BALF of patients with ARDS following trauma $[78,79]$ coupled with a strong relation of this biological marker to the severity of endothelial damage [80]. Moreover, a potential value of SP-A plasma levels in discriminating patients with ALI of various etiologic factors has also been shown [79]. On the other hand, little is known about changes in peripheral concentrations of surfactant-associated proteins in patients with ALI and whether these alterations can serve 
as markers of injury to the epithelial and endothelial barriers in the lungs.

Doyle et al. [81] documented elevated circulating concentrations of SP-A in patients with ARDS and in those with acute cardiogenic pulmonary edema possibly resulting from increased alveolocapillary permeability due to excessively high pulmonary capillary pressures. In the same study, blood SP-A levels were inversely associated with blood oxygenation and static respiratory system compliance. These results were fully confirmed by the same group of authors \{Doyle et al. [82]\} who also illustrated a clear superiority of SP-B compared to SP-A plasma levels as a marker of lung function and alveolocapillary membrane injury.

Another study by Greene et al. [83], evaluated the differences that occur in SPs in BALF and serum of a relatively small cohort of patients at risk for ARDS and during the course of the syndrome. Authors demonstrated that only SP-A and SP-D BALF levels were strongly related to outcome and likelihood of disease progression whereas serum changes found to be neither sensitive nor specific in predicting the onset of ARDS and discriminating survivors from non-survivors.

These data were further confirmed by a small cohort observational study by Cheng et al [84]. Even though authors reported an association of elevated SP-A plasma levels with a high degree of lung injury, they failed to extend this correlation with the disease mortality. Moreover, serum SP-D levels exhibited weak relation to the disease severity. It should also be noted that the aforementioned results present low statistical power due to the limited number of patients, the causal heterogeneity of the studied group and the absence of serial measurement and therefore no meaningful outcome can be excluded.

In harmony with the latter results, Greene et al. [85] found that plasma SP-A was weakly predictive for ARDS development in septic patients and were unable to detect at risk trauma patients that developed the syndrome. Additionally, authors raised the crucial issue whether circulating SPs can reflect pathophysiologic differences between direct and indirect causes of ARDS and subsequently detect biologic changes early after an insult. From a pragmatic clinical perspective the most important question to be answered is which ICU patients requiring ventilatory assistance will develop ARDS.

To do so Bersten et al. [86] generated ROC curve analysis and identified practical thresholds for SP-B plasma levels that could be clinically useful in predicting ARDS development, particularly in at-risk patients suffering a direct lung injury. In consistency with earlier studies [83-85] SPA blood levels added no significant information on the disease prognosis. Further, an increase of circulating SP-B concentrations was documented on study entry, before changes in commonly applied clinical variables for the assessment of lung injury become apparent. These findings emphasize the usefulness of surfactant-associated proteins for the early detection of ARDS pathophysiologic alterations preceding changes in clinical parameters such as respiratory dysfunction. Arguments that can be made include the small sample size, the limited sequential measurements and the exclusion from the study recruitment of at risk patients with milder pulmonary dysfunction. These caveats coupled with the evidence that a considerable number of patients studied had already lung injury, pose major limitations to the predictive capacity of SP-B plasma levels and raise the necessity for larger prospective studies.

The only so far large multicenter randomized controlled trial was performed by Eisner et al. [87] who estimated the prognostic value of SP-A and SP-D levels in an overall of 565 patients with early ALI/ARDS. Authors conducted the first study with adequate statistical power to examine the impact of SPs on mortality and other clinical variables and clearly demonstrated a strong linkage of elevated SP$\mathrm{D}$ levels with worse clinical outcomes such as greater risk of death, fewer ventilator- free and organ failure-free days. One of the most remarkable ascertainments of this study was the attenuation of SP-D plasma levels by the lower volume ventilation strategies which reduces patients' mortality postulating for the first time a significant association of biological parameters with therapeutic approaches and subsequently emphasizing the role of this mediator as a marker of the disease severity and prognosis. However, this study exhibited substantial weaknesses including the lack of sufficient serial measurements, a potential selection bias of patients recruited and the diversity of predisposing factors for ARDS development. These observations are not to diminish their value as prognostic and monitoring tools but to highlight the need for further confirmation studies using independent and well-defined populations of ALI/ARDS patients.

\section{Mucin-associated Antigens}

Mucins are major components of the mucus layer covering the airway epithelium. They consist of high-molecular-weight glycoproteins belonging to a broad family of mucin peptides [68]. Mucins are either associated with membranes or secreted at the surface of the respiratory tract [68]. Krebs von den Lungen-(KL)-6 is mainly associated with cellular membranes. It was initially described by Kohno et al. [70] as a high-molecular-weight glycoprotein and was classified as human MUC1 mucin. Immunohistochemistry has mainly detected KL-6 in alveolar type II 
and epithelial cells of the respiratory bronchioles. KL- 6 is predominantly expressed by airway cells; however, is not entirely lung specific, since it is also present on other somatic cells, such as pancreatic cells, eosophageal cells and fundic cells of the stomach [88]. Additionally, KL-6 is a sensitive indicator of damage to alveolar type II cells, which strongly express this mucin at their surface [70]. Type II pneumonocytes are regenerated over the alveolar basement membrane after the death of type I pneumonocytes over the first stage of lung injury. Therefore, its raise would theoretically represent the destruction of the normal lung parenchyma and architecture, the increased permeability of the air-blood barrier as long as the regenerating process as expressed by type II pneumonocytes' activity.

Towards this direction, the presence of KL- 6 has been extensively used with great promises to monitor the severity of disease in idiopathic pulmonary fibrosis [89-91] and other interstitial lung diseases [92-94]. Since damage to, and disruption of, the alveolar epithelial lining coupled with loss of integrity of the air-blood barrier represent key features in the pathophysiology of ARDS, KL-6 serum levels could potentially serve as valuable indicators of the disease severity directly assessing the degree of epithelial damage and predicting the progression to ARDS. Nevertheless, only few studies so far, have evaluated their monitoring and prognostic efficacy in patients with or at risk for ARDS development.

One of the first studies to do so was recently carried out by Ishizaka and co-workers [95]. Authors generated ROC curve analysis and documented a highly sensitive and specific association of optimal cut-off values of KL-6 serum levels with patients' mortality. The latter, further supports the premise that disruption of the alveolar barrier represents a major determinant of prognosis of ALI and that serial measurements of KL-6 plasma levels might be helpful markers of the disease progression. Limitations that should be addressed include the limited number of patients, the retrospective analysis of the results and the diversity of the etiologic factors of ALI generate major concerns about the reproducibility and the reliability of the data.

Recently, Sato et al. [96] sought to determine potential correlations of KL- 6 circulating concentrations with disease severity, patients' survival and different predisposing factors of ARDS. The most remarkable ascertainments of this study include strong associations of KL- 6 peripheral levels with variables of lung injury severity and with the rates of mortality indicating possible relationship between the degree of epithelial damage and poor outcome in ARDS. Even though, authors attempted to show a modulation of KL-6 serum levels by ventilatory strate- gies, this relationship failed to reach a statistical significance. Despite substantial weaknesses exhibited such as the lack of serial measurement, the small sample size and the diversity of the applied treatment data derived from this study is highly informative and provides important knowledge regarding the biological impact of mechanical support strategies in this syndrome indicating the monitoring value of the epithelial damage markers. Further and sizeable prospective studies are required to validate the aforementioned hypothesis (Table 7).

\section{Future challenges and limitations}

The ARDS represents an overwhelming inflammatory reaction to numerous insults within the pulmonary parenchyma resulting in life-threatening derangements in pulmonary vasomotion, alveolar ventilation and gas exchange. ARDS is a frequent disease with a devastating incidence between 13.5 and 75 per 100,000, thus affecting about $16-18 \%$ of all patients ventilated in the ICU $[76,97]$. Hence, ALI/ARDS is a major public health problem encountered frequently by all physicians who care for critically ill patients. Despite the fact that research efforts over the past several years have provided a more comprehensive knowledge of the potential mechanisms comprising the immunopathogenesis of ALI/ARDS and led to the development of innumerable causative or symptomatic treatment approaches, the mortality rate of these patients remains unacceptably high at 30-40\% [97]. Currently, the only therapy that has been proven to be effective at reducing mortality is a protective ventilatory strategy [98]. However, new therapies are still needed. One of the most fruitful applications is monitoring the disease activity and consequently the early identification of at risk patients with increased likelihood of nonresponse to treatment and progression to ARDS. Nevertheless, there are problems with the sensitivity, effortdependability and ease of repetition of the current modalities being used for this purpose, including radiological and BAL techniques as well as clinical and physiological indices of pulmonary injury (Murray score), systemic illness (Acute Physiology and Chronic Health EvaluationAPACHE-II score and Simplified Acute Physiological Score -SAPS), ARDS severity (respiratory system compliance and $\mathrm{PaO} 2 / \mathrm{FiO} 2$ ratio) and multiorgan system failure (Multi-Organ Dysfunction Score-MODS). Most of these clinical parameters have failed to be independent predictors of mortality in studies of adults with ALI/ARDS $[99,100]$. Development of a prognostic index that combines clinical and biological determinants may be useful to ameliorate these hardships.

On the basis of this conception, a large body of serum markers either cytokines and lung-specific proteins or markers of endothelium and neutrophil activation as well as other serological parameters probing different facets of 
the immunopathogenesis of ALI/ARDS has been delineated. The applications of these markers in the clinical setting created major expectations in terms of defining categories of patients for different therapies or prognosis for the purpose of counseling families and patients and/or possibly identifying novel therapeutic targets. The determination of a reliable serologic marker reflecting the disease behaviour and adding independent information regarding the development of the syndrome before it becomes obvious in clinical level, easily reproducible and feasible to be measured serially represents a major challenge. The early serial measurement of this biomarker may serve as an independent non-invasive prognosticator of the disease outcome even at the onset of the syndrome and therefore lead to an early detection of at risk patients with increased likelihood of progression to ARDS. The latter, if sufficiently accurate, could prove extremely useful in identifying and counseling families of patients at low or high risk for adverse outcomes and further, will allow ventilatory or other types of treatment to be evaluated or eventually modulated before they have failed in the high risk group. The presented data give credence to the view that multiple biomarkers can be used to measure the lung and systemic response to a protective ventilatory strategy and potentially to discriminate patients who are ineffectively treated and might be candidates for rescue therapies $[49,87]$.

More importantly, use of one or more of these biologic markers to select a group of patients at higher risk of adverse clinical outcome could be used to restrict or stratify enrollment in future clinical trials applying novel ventilator treatments such as high-frequency oscillatory ventilation leading to a better patient care. Thereby, a combination of clinical factors and biologic marker measurements could be crucial for the selection of more homogeneous groups of patients with ALI/ARDS for further studies producing evidence of high scientific rigidity [101]. Finally, understanding the relative roles of markers of systemic and pulmonary endothelial injury and other inflammatory mediators to the pathogenetic process of the syndrome is likely to lead to valuable insights into the final pathway resulting in diffuse alveolar damage and significant lung dysfunction, highlighting therapeutic targets for novel interventions. The aforementioned components can potentially compile a clinician's "wish list".

However, the feeling of excitement arising from the expected clinical utility comes in contrast with important deficiencies exhibited by the new methodologies including non-standardization techniques, lack of knowledge of reproducibility and link to disease behaviour. Furthermore, most of the studies enrolled a limited number of patients, insufficient to extract any meaningful or statistically significant outcome. In addition, the heterogeneity of the studied population resulting from the causal diversity of the syndrome and the use of non-uniform criteria for the definitions of ARDS and at-risk patients (Tables 2, $3,4,5)$ render major uncertainty to the reproducibility and the scientific rigidity of these findings and may explain potential discrepancies between various studies investigating different groups of at risk patients.

Moreover, many of the caveats arising from this data are generated by the origin disadvantages of the investigated serological parameters to serve as specific markers of the disease activity and severity. In particular, it is well known that assays of circulating cytokine concentration may be misleading, because they do not detect receptor or cellular bound cytokines, or they may fail to detect cytokines when inhibitors or receptor antagonists are present. Thus, measured cytokine concentrations may not reflect the disease activity or the state of inflammation but the increased production or decreased clearance from the circulation. In consistency with these limitations, it should be underlined that cytokines are part of an inflammatory cascade and biological effects are difficult even impossible to interpret without the appreciation of the entire network of the inflammatory response. Hence, data in most of the studies was inconclusive and incomplete since none of them analyzed serum alterations of a considerable number of inflammatory components.

Additionally, it is of high importance to note that unfortunately only few studied molecules (VWF, IL-1 $\beta$, IL-6, ICAM-1, VCAM-1) exhibited independent discriminatory power $[18,44,48,49]$ and associated with the mortality of patients with high sensitivity and specificity [45]. Finally, only the minority of the studies $[18,19,25$ $27,43,45,47,51,53,64,66,67,83,86,95]$ clarified the effectiveness and the diagnostic accuracy of the biomarkers by applying ROC curve analysis which is essential to estimate the sensitivity and specificity of a marker and to introduce clinically practical cut-off levels for the prediction of ARDS development in at risk individuals.

Collectively, these findings highlight the necessity for further investigations in the context of large prospective studies analyzing homogeneous and well defined group of ARDS or at risk patients and the assessment of novel molecules to serve as diagnostic and prognostic tools, as well as markers of the disease activity and severity.

\section{Conclusion}

Currently, the application status in routine clinical practice for most of these biologic markers is still in its infancy and remains exploratory. Unfortunately, they do not yield independent indications for therapy or mark the end of the inflammatory process and their prognostic value still needs to be established. Although the majority of them 
have not yet lived up to the "great hype" that was generated, markers of endothelium activation and mostly VWF and adhesion molecules (ICAM-1, VCAM-1, E-selectin) show the greatest promise in ARDS and ALI. On the contrary the majority of serum cytokines and ferritin appear to be not ready for routine monitoring since they may reflect an inflammatory response to a risk factor rather than lung injury and disease severity. Additionally, lung specific proteins have proven to be neither specific nor sensitive for the prediction of ARDS development and the disease outcome and moreover they have failed to associate with alterations in the ventilatory strategies in large clinical trials. Further prospective investigations, technical improvements and introduction of novel markers are warranted in order to elevate the association of serum biomarkers with the pathogenesis of ARDS in the same status as for tumour markers with lung cancer. Nevertheless, crossing the boundary from research to clinical application requires validation in multiple settings, experimental evidence supporting a pathophysiologic role, and ideally intervention trials showing that modification improves the outcome. The emergence of pioneering technologies including DNA microarrays which have already been applied with great success in the respiratory research field [102] can help scientists to circumvent this problem and bridge this boundary. In the interim, these markers can be quite useful to supplement the clinical, radiological and physiological monitoring of the disease and identify high-risk patients who would benefit from aggressive management of established risk factors.

\section{List of Abbreviations}

Acute Lung Injury (ALI)

Acute Physiology and Chronic Health Evaluation (APACHE)

Acute Respiratory Distress Syndrome (ARDS)

Bronchoalveolar lavage fluid (BALF)

ICU: Intensive Care Unit

ICAM-1: Intercellular Cell Adhesion Molecule-1

ILs: Interleukins

ILDs: Interstitial Lung Diseases

Krebs von den Lungen-(KL)-6

LTs: Leukotrienes

MMPs (Metalloproteinases)
MODS: Multi-Organ Dysfunction Score

Receiver-operating-characteristic (ROC)

Simplified Acute Physiological Score (SAPS)

SIRS: Systemic Inflammatory Response Syndrome

Soluble-E-selectin: s-E-selectin

Soluble IL-2 receptor (sIL-2R)

Surfactant protein-(SP)

TNFa: Tumor Necrosis Factor-alpha

VWF: von Willebrand factor

VCAM-1: Vascular Cell Adhesion Molecule-1

\section{Competing interests}

The author(s) declare that they have no competing interests.

\section{Authors' contributions}

AT, IP and DB were involved with the study conception. AT and IP performed the data acquisition and interpretation. DB was involved in revising the article for important intellectual content. All authors read and approved the final manuscript.

\section{Acknowledgements}

The authors are grateful to Stavros Anevlavis (M.D) for his valuable assistance in collecting the data and revising the article.

\section{References}

I. Ferrigno D, Buccheri G, Biggi A: Serum tumour markers in lung cancer: history, biology and clinical applications. Eur Respir J 1994, 7:186-97.

2. Manolio T: Novel risk markers and clinical practice. $N$ Engl J Med 2003, 23(349): I587-9.

3. Bernard GR, Artigas A, Brigham KL, Carlet J, Falke K, Hudson L, Lamy M, Legall JR, Morris A, Spragg R: The American-European Consensus Conference on ARDS. Definitions, mechanisms, relevant outcomes, and clinical trial coordination. Am J Respir Crit Care Med 1994, 149:818-24.

4. Fowler AA, Hamman RF, Good JT, Benson KN, Baird M, Eberle DJ, Petty TL, Hyers TM: Adult respiratory distress syndrome: risk with common predispositions. Ann Intern Med 1983, 98:593-7.

5. Rinaldo JE, Christman JW: Mechanisms and mediators of the adult respiratory distress syndrome. Clin Chest Med 1990, I I:62I-32.

6. Pugin J, Ricou B, Steinberg KP, Suter PM, Martin TR: Proinflammatory activity in bronchoalveolar lavage fluids from patients with ARDS, a prominent role for interleukin-I. Am J Respir Crit Care Med 1996, 153:1850-6.

7. Torii K, lida K, Miyazaki Y, Saga S, Kondoh Y, Taniguchi H, Taki F, Takagi K, Matsuyama M, Suzuki R: Higher concentrations of matrix metalloproteinases in bronchoalveolar lavage fluid of patients with adult respiratory distress syndrome. Am J Respir Crit Care Med 1997, 155:43-6. 
8. Meduri GU, Kanangat S, Stefan J, Tolley E, Schaberg D: Cytokines IL-Ibeta, IL-6, and TNF-alpha enhance in vitro growth of bacteria. Am J Respir Crit Care Med 1999, 160:96I-7.

9. Park WY, Goodman RB, Steinberg KP, Ruzinski IT, Radella F 2nd, Park DR, Pugin J, Skerrett SJ, Hudson LD, Martin TR: Cytokine balance in the lungs of patients with acute respiratory distress syndrome. Am J Respir Crit Care Med 200I, 164:1896-903.

10. Tracey KJ, Beutler B, Lowry SF, Merryweather J, Wolpe S, Milsark IW, Hariri RJ, Fahey TJ 3rd, Zentella A, Albert JD: Shock and tissue injury induced by recombinant human cachectin. Science 1986, 234:470-4.

II. Marks JD, Marks CB, Luce JM, Montgomery AB, Turner J, Metz CA Murray JF: Plasma tumor necrosis factor in patients with septic shock. Mortality rate, incidence of adult respiratory distress syndrome, and effects of methylprednisolone administration. Am Rev Respir Dis 1990, 141:94-7.

12. Damas P, Reuter A, Gysen P, Demonty J, Lamy M, Franchimont P. Tumornecrosis factor and interleukin-I serum levels during severe sepsis in humans. Crit Care Med 1989, 17:975-8.

13. Pinsky MR, Vincent JL, Deviere J, Alegre M, Kahn RJ, Dupont E: Serum cytokine levels in human septic shock. Relation to multiple-system organ failure and mortality. Chest 1993, 103:565-75.

14. Takala A, Jousela I, Jansson SE, Olkkola KT, Takkunen O, Orpana A, Karonen SL, Repo $\mathrm{H}$ : Markers of systemic inflammation predicting organ failure in community-acquired septic shock. Clin Sci (Lond) 1999, 97:529-38.

15. Calandra T, Gerain J, Heumann D, Baumgartner JD, Glauser MP High circulating levels of interleukin-6 in patients with septic shock: evolution during sepsis, prognostic value, and interplay with other cytokines. The Swiss-Dutch J5 Immunoglobulin Study Group. Am J Med I99I, 9 I:23-9.

16. Kiehl MG, Ostermann H, Thomas M, Muller C, Cassens U, Kienast J: Inflammatory mediators in bronchoalveolar lavage fluid and plasma in leukocytopenic patients with septic shock-induced acute respiratory distress syndrome. Crit Care Med 1998, 26:1194-9.

17. Meduri GU, Kohler G, Headley S, Tolley E, Stentz F, Postlethwaite A: Inflammatory cytokines in the BAL of patients with ARDS. Persistent elevation over time predicts poor outcome. Chest 1995, 108:1303-14.

18. Meduri GU, Headley S, Kohler G, Stentz F, Tolley E, Umberger R, Leeper K: Persistent elevation of inflammatory cytokines predicts a poor outcome in ARDS. Plasma IL-I beta and IL- 6 levels are consistent and efficient predictors of outcome over time. Chest 1995, 107:1062-73.

19. Agouridakis P, Kyriakou D, Alexandrakis MG, Perisinakis K, Karkavitsas N, Bouros D: Association between increased levels of IL-2 and IL- I5 and outcome in patients with early acute respiratory distress syndrome. Eur J Clin Invest 2002, 32:862-7.

20. Lesur O, Kokis A, Hermans C, Fulop T, Bernard A, Lane D: Interleukin-2 involvement in early acute respiratory distress syndrome: relationship with polymorphonuclear neutrophil apoptosis and patient survival. Crit Care Med 2000, 28:38I4-22.

21. Headley AS, Tolley E, Meduri GU: Infections and the inflammatory response in acute respiratory distress syndrome. Chest 1997, I I I:|306-2I.

22. Goodman RB, Strieter RM, Martin DP, Steinberg KP, Milberg JA, Maunder RJ, Kunkel SL, Walz A, Hudson LD, Martin TR: Inflammatory cytokines in patients with persistence of the acute respiratory distress syndrome. Am J Respir Crit Care Med 1996, 154:602-II.

23. Parsons PE, Moss M, Vannice JL, Moore EE, Moore FA, Repine JE: Circulating IL-I ra and IL- IO levels are increased but do not predict the development of acute respiratory distress syndrome in at-risk patients. Am J Respir Crit Care Med 1997, 155:1469-73.

24. Takala A, Jousela I, Takkunen O, Kautiainen H, Jansson SE, Orpana A, Karonen SL, Repo $\mathrm{H}$ : A prospective study of inflammation markers in patients at risk of indirect acute lung injury. Shock 2002, 17:252-7.

25. Bouros D, Alexandrakis MG, Antoniou KM, Agouridakis P, Pneumatikos I, Anevlavis S, Pataka A, Patlakas G, Karkavitsas N, Kyriakou D The clinical significance of serum and bronchoalveolar lavage inflammatory cytokines in patients at risk for Acute Respiratory Distress Syndrome. BMC Pulm Med 2004, 4:6.
26. Schutte $\mathrm{H}$, Lohmeyer J, Rosseau S, Ziegler S, Siebert $\mathrm{C}$, Kielisch $\mathrm{H}$, Pralle H, Grimminger F, Morr H, Seeger W: Bronchoalveolar and systemic cytokine profiles in patients with ARDS, severe pneumonia and cardiogenic pulmonary oedema. Eur Respir J 1996, 9:1858-67.

27. Bauer TT, Monton C, Torres A, Cabello H, Fillela X, Maldonado A, Nicolas JM, Zavala E: Comparison of systemic cytokine levels in patients with acute respiratory distress syndrome, severe pneumonia, and controls. Thorax 2000, 55:46-52.

28. Parrillo JE: Pathogenetic mechanisms of septic shock. N Engl J Med 1993, 328:147I-7.

29. Osborn L: Leukocyte adhesion to endothelium in inflammation. Cell 1990, 62:3-6.

30. Springer TA: Traffic signals for lymphocyte recirculation and leukocyte emigration: the multistep paradigm. Cell 1994, 76:30I-14.

31. Springer TA: Adhesion receptors of the immune system. Nature 1990, 346:425-34.

32. Stoolman LM: Adhesion molecules involved in leukocyte recruitment and lymphocyte recirculation. Chest 1993, 103:79S-86S

33. Gearing AJ, Newman W: Circulating adhesion molecules in disease. Immunol Today 1993, 14:506-12.

34. Newman W, Beall LD, Carson CW, Hunder GG, Graben N, Randhawa ZI, Gopal TV, Wiener-Kronish J, Matthay MA: Soluble Eselectin is found in supernatants of activated endothelial cells and is elevated in the serum of patients with septic shock. J Immunol I993, I 50:644-54.

35. Rothlein R, Mainolfi EA, Czajkowski M, Marlin SD: A form of circulating ICAM-I in human serum. J Immunol I99I, 147:3788-93.

36. Rossi EC, Green D, Rosen JS, Spies SM, Jao JS: Sequential changes in factor VIII and platelets preceding deep vein thrombosis in patients with spinal cord injury. $\mathrm{Br} J$ Haematol 1980, 45: $|43-5|$.

37. Ribes JA, Francis CW, Wagner DD: Fibrin induces release of von Willebrand factor from endothelial cells. J Clin Invest 1987, 79: II7-23.

38. Hamilton KK, Sims PJ: Changes in cytosolic Ca2+ associated with von Willebrand factor release in human endothelial cells exposed to histamine. Study of microcarrier cell monolayers using the fluorescent probe indo-I. J Clin Invest 1987, 79:600-8.

39. Donnelly SC, Haslett C, Dransfield I, Robertson CE, Carter DC, Ross JA, Grant IS, Tedder TF: Role of selectins in development of adult respiratory distress syndrome. Lancet 1994, 23(344):215-9.

40. Boldt J, Wollbruck M, Kuhn D, Linke LC, Hempelmann G: Do plasma levels of circulating soluble adhesion molecules differ between surviving and nonsurviving critically ill patients? Chest 1995, 107:787-92.

4I. Cowley HC, Heney D, Gearing AJ, Hemingway I, Webster NR: Increased circulating adhesion molecule concentrations in patients with the systemic inflammatory response syndrome: a prospective cohort study. Crit Care Med 1994, 22:65I-7.

42. Redl $H$, Dinges HP, Buurman WA, van der Linden CJ, Pober JS, Cotran RS, Schlag G: Expression of endothelial leukocyte adhesion molecule-I in septic but not traumatic/hypovolemic shock in the baboon. Am J Pathol 1991, 139:46I-6.

43. Sessler CN, Windsor AC, Schwartz M, Watson L, Fisher BJ, Sugerman $H$, Fowler AA 3rd: Circulating ICAM-I is increased in septic shock. Am / Respir Crit Care Med I995, I 5 I: | 420-7.

44. Kayal S, Jais JP, Aguini N, Chaudiere J, Labrousse J: Elevated circulating E-selectin, intercellular adhesion molecule $I$, and von Willebrand factor in patients with severe infection. $\mathrm{Am} \mathrm{J}$ Respir Crit Care Med 1998, I 57:776-84.

45. Agouridakis $P$, Kyriakou D, Alexandrakis MG, Prekates A, Perisinakis $K$, Karkavitsas N, Bouros D: The predictive role of serum and bronchoalveolar lavage cytokines and adhesion molecules for acute respiratory distress syndrome development and outcome. Respir Res 2002, 3:25.

46. Carvalho AC, Bellman SM, Saullo VJ, Quinn D, Zapol WM: Altered factor VIII in acute respiratory failure. $N$ Engl J Med 1982, 307: III3-9.

47. Rubin DB, Wiener-Kronish JP, Murray JF, Green DR, Turner J, Luce JM, Montgomery AB, Marks JD, Matthay MA: Elevated von Wille- 
brand factor antigen is an early plasma predictor of acute lung injury in nonpulmonary sepsis syndrome. J Clin Invest 1990, 86:474-80.

48. Ware LB, Conner ER, Matthay MA: von Willebrand factor antigen is an independent marker of poor outcome in patients with early acute lung injury. Crit Care Med 200I, 29:2325-3I.

49. Ware LB, Eisner MD, Thompson BT, Parsons PE, Matthay MA: Significance of von Willebrand factor in septic and nonseptic patients with acute lung injury. Am J Respir Crit Care Med 2004, I 70:766-72.

50. Moalli R, Doyle JM, Tahhan HR, Hasan FM, Braman SS, Saldeen T: Fibrinolysis in critically ill patients. Am Rev Respir Dis 1989, I 40:287-93.

5I. Moss M, Ackerson L, Gillespie MK, Moore FA, Moore EE, Parsons PE: von Willebrand factor antigen levels are not predictive for the adult respiratory distress syndrome. Am J Respir Crit Care Med 1995, I $51: 15-20$

52. Sabharwal AK, Bajaj SP, Ameri A, Tricomi SM, Hyers TM, Dahms TE, Taylor FB Jr, Bajaj MS: Tissue factor pathway inhibitor and von Willebrand factor antigen levels in adult respiratory distress syndrome and in a primate model of sepsis. Am J Respir Crit Care Med 1995, I5 I:758-67.

53. Bajaj MS, Tricomi SM: Plasma levels of the three endothelialspecific proteins von Willebrand factor, tissue factor pathway inhibitor, and thrombomodulin do not predict the development of acute respiratory distress syndrome. Intensive Care Med 1999, 25:1259-66.

54. Moss M, Gillespie MK, Ackerson L, Moore FA, Moore EE, Parsons PE: Endothelial cell activity varies in patients at risk for the adult respiratory distress syndrome. Crit Care Med 1996, 24: I 782-6.

55. Ognibene FP, Martin SE, Parker MM, Schlesinger T, Roach P, Burch C, Shelhamer JH, Parrillo JE: Adult respiratory distress syndrome in patients with severe neutropenia. N Engl J Med 1986, 3 15:547-5I.

56. Martin TR, Pistorese BP, Hudson LD, Maunder RJ: The function of lung and blood neutrophils in patients with the adult respiratory distress syndrome. Implications for the pathogenesis of lung infections. Am Rev Respir Dis 1991, 144:254-62.

57. Shapiro SD: Elastolytic metalloproteinases produced by human mononuclear phagocytes. Potential roles in destructive lung disease. Am J Respir Crit Care Med 1994, I 50:SI60-4.

58. Delclaux C, Delacourt C, D'Ortho MP, Boyer V, Lafuma C, Harf A: Role of gelatinase $B$ and elastase in human polymorphonuclear neutrophil migration across basement membrane. Am J Respir Cell Mol Biol 1996, I 4:288-95.

59. Sengelov H, Follin P, Kjeldsen L, Lollike K, Dahlgren C, Borregaard N Mobilization of granules and secretory vesicles during in vivo exudation of human neutrophils. J Immunol 1995, I 54:4I 57-65.

60. Pugin J, Verghese G, Widmer MC, Matthay MA: The alveolar space is the site of intense inflammatory and profibrotic reactions in the early phase $f$ acute respiratory distress syndrome. Crit Care Med 1999, 27:304-12.

61. Stephenson AH, Lonigro AJ, Hyers TM, Webster RO, Fowler AA: Increased concentrations of leukotrienes in bronchoalveolar lavage fluid of patients with ARDS or at risk for ARDS. Am Rev Respir Dis 1988, 138:7|4-9.

62. Ratnoff WD, Matthay MA, Wong MY, Ito Y, Vu KH, Wiener-Kronish J, Goetzl EJ: Sulfidopeptide-leukotriene peptidases in pulmonary edema fluid frompatients with the adult respiratory distress syndrome. J Clin Immunol 1988, 8:250-8.

63. Antonelli M, Raponi G, Lenti L, Severi L, Capelli O, Riccioni L, De Blasi RA, Conti G, Mancini C: Leukotrienes and alpha tumor necrosis factor levels in the bronchoalveolar lavage fluid of patient at risk for the adult respiratory distress syndrome. Minerva Anestesiol 1994, 60:419-26.

64. Amat M, Barcons M, Mancebo J, Mateo J, Oliver A, Mayoral JF, Fontcuberta J, Vila L: Evolution of leukotriene B4, peptide leukotrienes, and interleukin-8 plasma concentrations in patients at risk of acute respiratory distress syndrome and with acute respiratory distress syndrome: mortality prognostic study. Crit Care Med 2000, 28:57-62.

65. Hirayama M, Kohgo Y, Kondo H, Shintani N, Fujikawa K, Sasaki K, Kato J, Niitsu Y: Regulation of iron metabolism in HepG2 cells: a possible role for cytokines in the hepatic deposition of iron. Hepatology 1993, I 8:874-80.
66. Connelly KG, Moss M, Parsons PE, Moore EE, Moore FA, Giclas PC, Seligman PA, Repine JE: Serum ferritin as a predictor of the acute respiratory distress syndrome. Am J Respir Crit Care Med 1997, | 55:21-5.

67. Sharkey RA, Donnelly SC, Connelly KG, Robertson CE, Haslett C, Repine JE: Initial serum ferritin levels in patients with multiple trauma and the subsequent development of acute respiratory distress syndrome. Am J Respir Crit Care Med 1999, I59:1506-9.

68. Hermans C, Bernard A: Lung epithelium-specific proteins: characteristics and potential applications as markers. Am J Respir Crit Care Med 1999, 159:646-78.

69. Reynolds HY, Newball $\mathrm{HH}$ : Analysis of proteins and respiratory cells obtained from human lungs by bronchial lavage. J Lab Clin Med 1974, 84:559-73.

70. Kohno N, Kyoizumi S, Awaya Y, Fukuhara H, Yamakido M, Akiyama $M$ : New serum indicator of interstitial pneumonitis activity. Sialylated carbohydrate antigen KL-6. Chest 1989, 96:68-73.

7I. King RJ, Klass DJ, Gikas EG, Clements JA: Isolation of apoproteins from canine surface active material. Am J Physiol 1973, 224:788-95

72. Possmayer F: A proposed nomenclature for pulmonary surfactant-associated proteins. Am Rev Respir Dis 1988, 138:990-8.

73. Creuwels LA, van Golde LM, Haagsman HP: The pulmonary surfactant system: biochemical and clinical aspects. Lung I997, I75:1-39.

74. Nieman GF, Bredenberg CE: High surface tension pulmonary edema induced by detergent aerosol. I Appl Physiol 1985, 58:29-36.

75. Griese M: Pulmonary surfactant in health and human lung diseases: state of the art. Eur Respir J 1999, I 3: |455-76.

76. Gunther A, Ruppert C, Schmidt R, Markart P, Grimminger F, Walmrath D, Seeger W: Surfactant alteration and replacement in acute respiratory distress syndrome. Respir Res 2001, 2:353-64.

77. Griese M: Pulmonary surfactant in health and human lung diseases: state of the art. Eur Respir J 1999, I 3: |455-76.

78. Gregory TJ, Longmore WJ, Moxley MA, Whitsett JA, Reed CR, Fowler AA 3rd, Hudson LD, Maunder RJ, Crim C, Hyers TM: Surfactant chemical composition and biophysical activity in acute respiratory distress syndrome. J Clin Invest 1991, 88: $|976-8|$.

79. Gunther A, Siebert C, Schmidt R, Ziegler S, Grimminger F, Yabut M, Temmesfeld B, Walmrath D, Morr H, Seeger W: Surfactant alterations in severe pneumonia, acute respiratory distress syndrome, and cardiogenic lung edema. Am J Respir Crit Care Med 1996, I53:176-84.

80. Pison U, Obertacke U, Seeger W, Hawgood S: Surfactant protein A (SP-A) is decreased in acute parenchymal lung injury associated with polytrauma. Eur J Clin Invest 1992, 22:712-8.

8I. Doyle IR, Nicholas TE, Bersten AD: Serum surfactant protein-A levels in patients with acute cardiogenic pulmonary edema and adult respiratory distress syndrome. Am J Respir Crit Care Med 1995, I 52:307-17.

82. Doyle IR, Bersten AD, Nicholas TE: Surfactant proteins-A and -B are elevated in plasma of patients with acute respiratory failure. Am J Respir Crit Care Med 1997, I 56:1217-29.

83. Greene KE, Wright JR, Steinberg KP, Ruzinski JT, Caldwell E, Wong WB, Hull W, Whitsett JA, Akino T, Kuroki Y, Nagae H, Hudson LD, Martin TR: Serial changes in surfactant-associated proteins in lung and serum before and after onset of ARDS. Am J Respir Crit Care Med 1999, 160:1843-50.

84. Cheng IW, Ware LB, Greene KE, Nuckton TJ, Eisner MD, Matthay MA: Prognostic value of surfactant proteins $A$ and $D$ in patients with acute lung injury. Crit Care Med 2003, 3 I:20-7.

85. Greene KE, Ye S, Mason RJ, Parsons PE: Serum surfactant protein-A levels predict development of ARDS in at-risk patients. Chest 1999, I 16:90S-9IS.

86. Bersten AD, Hunt T, Nicholas TE, Doyle IR: Elevated plasma surfactant protein-B predicts development of acute respiratory distress syndrome in patients with acute respiratory failure. Am J Respir Crit Care Med 200I, I 64:648-52.

87. Eisner MD, Parsons P, Matthay MA, Ware L, Greene K: Acute Respiratory Distress Syndrome Network. Plasma surfactant protein levels and clinical outcomes in patients with acute lung injury. Thorax 2003, 58:983-8. 
88. Kohno N, Akiyama M, Kyoizumi S, Hakoda M, Kobuke K, Yamakido $M$ : Detection of soluble tumor-associated antigens in sera and effusions using novel monoclonal antibodies, KL-3 and KL-6, against lung adenocarcinoma. Jpn J Clin Oncol 1988, I 8:203-16.

89. Yanaba K, Hasegawa M, Hamaguchi Y, Fujimoto M, Takehara K, Sato S: Longitudinal analysis of serum KL-6 levels in patients with systemic sclerosis: association with the activity of pulmonary fibrosis. Clin Exp Rheumatol 2003, 2 I:429-36.

90. Yanaba K, Hasegawa M, Takehara K, Sato S: Comparative study of serum surfactant protein-D and KL-6 concentrations in patients with systemic sclerosis as markers for monitoring the activity of pulmonary fibrosis. J Rheumatol 2004, 3 I : I I I 2-20.

91. Ishii H, Mukae H, Kadota J, Kaida H, Nagata T, Abe K, Matsukura S, Kohno S: High serum concentrations of surfactant protein $\mathbf{A}$ in usual interstitial pneumonia compared with non-specific interstitial pneumonia. Thorax 2003, 58:52-7.

92. Ohnishi H, Yokoyama a, Yasuhara Y, Watanabe A, Naka T, Hamada H, Abe M, Nishimura K, Higaki J, Ikezoe J, Kohno N: Circulating KL6 levels in patients with drug induced pneumonitis. Thorax 2003, 58:872-5.

93. Kohno N, Hamada H, Fujioka S, Hiwada K, Yamakido M, Akiyama M: Circulating antigen KL-6 and lactate dehydrogenase for monitoring irradiated patients with lung cancer. Chest 1992, 1 02: I 17-22.

94. Goto K, Kodama T, Sekine I, Kakinuma R, Kubota K, Hojo F, Matsumoto T, Ohmatsu H, Ikeda H, Ando M, Nishiwaki Y: Serum levels of KL-6 are useful biomarkers for severe radiation pneumonitis. Lung Cancer 200I, 34:|4|-8.

95. Ishizaka A, Matsuda T, Albertine KH, Koh H, Tasaka S, Hasegawa N, Kohno N, Kotani T, Morisaki H, Takeda J, Nakamura M, Fang X, Martin TR, Matthay MA, Hashimoto S: Elevation of KL-6, a lung epithelial cell marker, in plasma and epithelial lining fluid in acute respiratory distress syndrome. Am J Physiol Lung Cell Mol Physiol 2004, 286:L1088-94.

96. Sato H, Callister ME, Mumby S, Quinlan GJ, Welsh KI, duBois RM, Evans TW: KL-6 levels are elevated in plasma from patients with acute respiratory distress syndrome. Eur Respir J 2004, 23: $142-5$.

97. Reynolds HN, McCunn M, Borg U, Habashi N, Cottingham C, BarLavi $Y$ : Acute respiratory distress syndrome: estimated incidence and mortality rate in a 5 million-person population base. Crit Care 1998, 2:29-34.

98. The Acute Respiratory Distress Syndrome Network: Ventilation with lower tidal volumes as compared with traditional tidal volumes for acute lung injury and the acute respiratory distress syndrome. N Engl J Med 2000, 342: I301-8.

99. Zilberberg MD, Epstein SK: Acute lung injury in the medical ICU: comorbid conditions, age, etiology, and hospital outcome. Am J Respir Crit Care Med 1998, I 57:| I 59-64.

100. Monchi M, Bellenfant F, Cariou A, Joly LM, Thebert D, Laurent I, Dhainaut JF, Brunet $F$ : Early predictive factors of survival in the acute respiratory distress syndrome. A multivariate analysis. Am J Respir Crit Care Med 1998, I 58: 1076-8I.

I0I. Ware LB: Prognostic determinants of acute respiratory distress syndrome in adults: impact on clinical trial design. Crit Care Med 2005, 33:S217-22

102. Tzouvelekis A, Patlakas G, Bouros D: Application of microarray technology in pulmonary diseases. Respir Res 2004, 5:26.

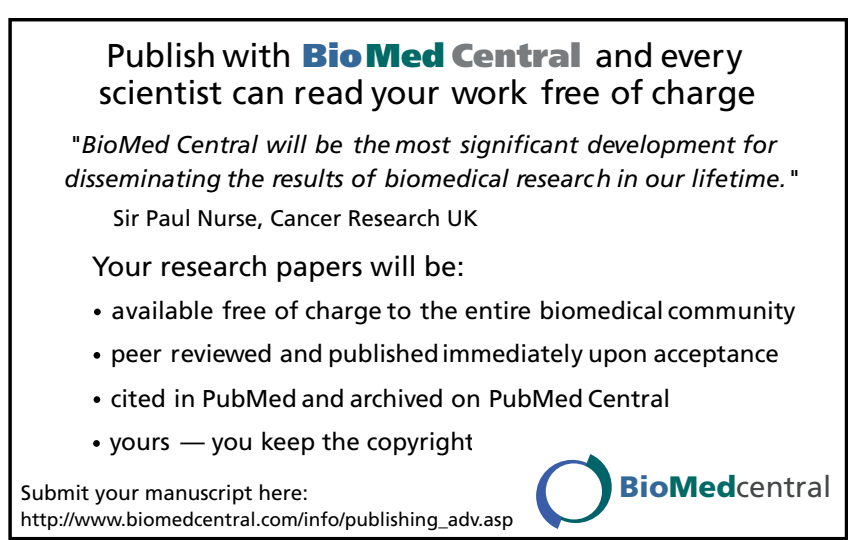

